\title{
Discontinuous, asymmetric and irregular colour patterns in Silurian oncocerids (Nautiloidea) with cyrtoconic shells
}

\author{
VoJTĚCH TUREK \& ŠTĚPÁN MANDA
}

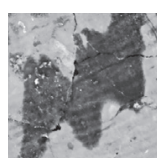

\begin{abstract}
The colour pattern is a conspicuous character of nautiloid shells. Better understanding to its evolution and possible function is limited by the rarity of preservation. The majority of colour patterns are preserved in demersal late Silurian breviconic oncocerids, while in other cephalopod orders and shell forms, it is limited or unknown. The colour pattern of late Silurian oncocerids (Oonoceratidae Flower, 1942 and Oocerinidae Teichert, 1939) possessing cyrtoconic and slightly curved shells is documented in nine species from Bohemia belonging to five genera. The cyrtocones Richardsonoceras Foerste, 1933 and Oonoceras Hyatt, 1884 exhibit slightly irregular oblique zig-zag patterns, which may be disrupted and may pass into irregular patches of dark pigment. By contrast, the colour pattern in Oocerina Foerste, 1926, possessing similar shell shape to Oonoceras, consists of narrow, transversal, slightly undulated bands. The short and very slightly curved shell of Chromatoceras gen. nov. displays bilaterally asymmetrical irregular bands or, as in the type species, irregular, asymmetrical, strongly discontinuous colouration. Distinct changes of patterning throughout ontogeny are documented herein in oncocerids, including narrowing of bands, irregular juvenile colouration passing into zig-zag bands and ventrally disappearing colouration in adult shell. Bilaterally asymmetric and irregular pattern, for the first time documented in nautiloids, appeared in probably more demersal cephalopods. The asymmetrical pattern exhibits high intraspecific variation unknown in other nautiloids. All studied oncocerids likely inhabited euphotic zone and the primary function of the colour patterns is camouflage. $\bullet$ Key words: Multiceratia, Oncocerida, Bohemia, asymmetric colouration, ontogeny, protective function.
\end{abstract}

Turek, V. \& Manda, Š. 2020. Discontinuous, asymmetric and irregular colour patterns in Silurian oncocerids (Nautiloidea) with cyrtoconic shells. Bulletin of Geosciences 95(3), 333-367 (20 figures, 2 tables). Czech Geological Survey, Prague. ISSN 1214-1119. Manuscript received July 16, 2019; accepted in revised form June 1, 2020; published online August 9, 2020; issued August 9, 2020.

Vojtěch Turek, Department of Palaeontology, National Museum, Václavské náměstí 68, CZ-110 00 Praha 1, Czech Republic; vojtech.turek@nm.cz• Štěpán Manda, Division of Regional Geology of Sedimentary Formations, Czech Geological Survey, PO Box 85, Praha 011, 118 21, Czech Republic

Shell colour patterns belong to the more prominent phenotypic characters in ectocochleate cephalopods. The origin and biological function of colour patterns is a matter of ongoing discussions and well-founded data concerning its evolution are still very limited (Williams 2017). However, the poor knowledge on colour patterns in fossil ectocochleate cephalopods significantly increased in the last decades (Mapes \& Davis 1996, Turek \& Manda 2011, Mapes \& Larson 2016). Colour patterning of the nautiloid shell was studied in relation to animal phenotype, autecology, habitat and taphonomy; the applicability for nautiloid taxonomy was discussed (Ruedemann 1921, Foerste 1930a, Kobluk \& Mapes 1989, Mapes \& Davis 1996, Manda \& Turek 2009a).

Up to now, colour patterns are documented in 47 early Palaeozoic nautiloid species (for a list with references, see Tab. 1). We have not regarded those species, in which colour patterns were mentioned (Foerste 1930a, Strids- berg 1985) but neither illustrated nor described in detail (see Turek 2009).

Colour patterns in Early Palaeozoic nautiloids have been recorded in representatives of the orders Oncocerida, Discosorida, (both subclass Multiceratia), Tarphycerida and Nautilida, while colour patterning in evolutionary older Cambrian and Early Ordovician nautiloids is still unknown. The vast majority of species displaying colour patterns belong to the order Oncocerida possessing straight or slightly curved breviconic shells (Barrande 1865-1870, Foerste 1930a). Colour patterns in oncocerids with coiled or almost straight shell were documented in only a few cases (Manda \& Turek 2009a, Turek 2009). Oncocerids display a high disparity of their shell form, ranging from straight, slowly expanding to coiled, trochoceraconic forms (Sweet 1964, Dzik 1984, Manda \& Turek 2009b), which is linked to the disparity in colour patterns. The colour patterning in Multiceratia includes longitudinal and 
transversal bands and their combination, densely spaced wave bands, zig-zag bands, chevron patterns and bands combined with irregularly dislocated patches of darker pigment that is in some cases associated with some other pattern (Foerste 1930a, Teichert 1964, Manda \& Turek 2009b). All these observed types are interpreted as true colour patterns. Regardless of variations, the patterns are not random; they are characteristic for individual taxa and the bands are not parallel to growth lines or other sculpture elements. False colour patterns on cephalopod shells, most common where thickening of the shell is present, have been discussed in more detail by Mapes \& Davis (1996), Klug et al. (2007), Mapes \& Larson (2016), A great deal of attention to pigmentation and formation of colour pattern in molluscs shells paid Meinhard (2009), Gunji et al. (1999) and Hammer \& Bucher (1999). In agreement with their conclusions dominating discontinuous zig-zag bands with other associate aspects of the colour patterns in cephalopods are characteristic for patterns self-organized by diffusion-reaction processes.

Until now, limited data has been published about colour patterns in nautiloids with exogastric, slowly and moderately expanding curved shell, i.e. forms that occur frequently in Early Palaeozoic cephalopod faunas. Here, we add descriptions of colour patterns in seven Silurian oncocerids of the family Oonoceratidae Flower, 1942 and Oocerinidae Teichert, 1939 including two species that were insufficiently illustrated or inadequately schematised by Barrande $(1866,1877)$. The new genus Chromatoceras gen. nov. is introduced and its distinct asymmetric colour pattern is considered as one of its diagnostic features. A summary of all Early Palaeozoic nautiloids displaying colour pattern is presented. We also focused on the variation in colour pattern, its species-specific characteristics, evolution and palaeobiological function.

\section{Material and methods}

Twenty-one specimens with preserved colour pattern are included in the present study. Seven specimens come from the historical Barrande's collection, other specimens were collected during field research over the past forty years. The specimens come from the Silurian rocks of an erosional remnant of a marine sedimentary succession of the Prague Basin (Lower Ordovician-Middle Devonian), which formed a part of a peri-Gondwanan terrain during the Early Palaeozoic. Most of the material was found in the cephalopod limestone, a time specific Silurian biofacies (Ferretti \& Křǐž 1995). The specimens come from the upper part of the Kopanina Formation, which corresponds to the upper Ludlow to lowermost Př́idolí Series (Kř́ž 1992, 1998). Only one specimen was discovered in the carbonate facies of the Požáry Formation of the uppermost Př́dolí Series (Kříž 1992, 1998).
Herein, we use the graptolite biozonation of the upper Ludlow Series according to Štorch et al. (2014) and Slavík et al. (2014); graptolite biozones of the Př́idolí Series are adopted from Kř́źž et al. (1986); ultimus and parultimus biozones are combined according to the global graptolite zonal chart (Koren et al. 1996).

The morphological terminology is mostly adopted from Teichert (1964). The shells of the specimens discussed herein are slightly to moderately curved. The shell shape and angle of expansion changed during ontogeny in most oncocerid species to varying degrees. For measurement of the angle of shell expansion (ae), a shorter segment of the shell with constant shell expansion was taken into account using the following parameters: $\mathrm{sh}_{1}, \mathrm{sh}_{2}$ (= dorsoventral shell height) and shell segment length sl (= the chord line distance between centres of $\mathrm{sh}_{1}, \mathrm{sh}_{2}$ ). The parameters used to calculate the $\mathrm{sh} / \mathrm{sw}$ (shell height/shell width) ratios were measured as close to the aperture as possible, where these values were not affected by damage or weathering. The term "longicone" is used for very slowly expanding shells and "brevicone" for rapidly expanding shells; these are not precisely defined (see Teichert 1964). Here, we use the term longicone or longiconic (very slowly expanding shell - up to $5^{\circ}$ ), slowly expanding (up to $10^{\circ}$ ), moderately expanding (up to $20^{\circ}$ ), and rapidly expanding conchs (up to $30^{\circ}$ ) while the term brevicone or breviconic includes conch forms with an angle of shell expansion exceeding $30^{\circ}$. Breviconic shells are also characterized by the proportion between height and length; a brevicone is typically short with shell length less than three times of the shell height.

As the colour bands are much better visible when the shell is wet, all specimens were immersed in alcohol or water before photographing to enhance the contrast. Some specimens were whitened with ammonium chloride before photographing. For this purpose, the equipment illustrated in text-fig. 4 by Parsley et al. (2018) was used.

All specimens studied are deposited in the collection of the National Museum, Prague (prefix NM).

\section{Description of colour pattern}

For the systematic description of the new genus Chromatoceras see the Taxonomic appendix below. Abbreviations: sl - maximum shell length; sh - maximum shell height; sw - shell width; bcl - body chamber length; ae - angle of shell expansion.

Family Oonoceratidae Flower, 1942

Richardsonoceras forbesi (Barrande, 1866)

Figures 1, 2

Material. - Four specimens NM-L 46534 (leg. V. Turek), 


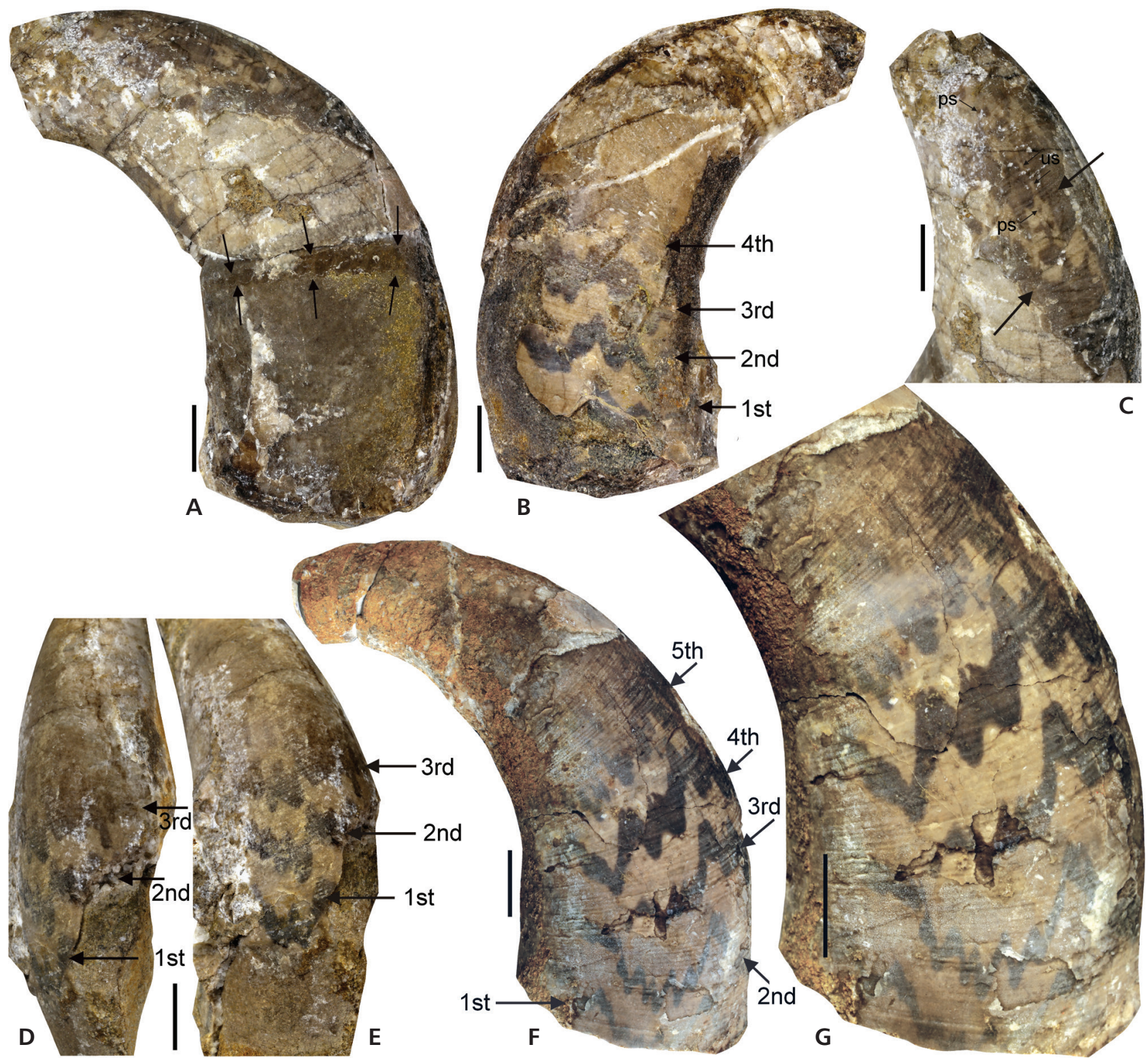

Figure 1. Richardsonoceras forbesi (Barrande, 1866); Ludlow Series, uppermost Ludfordian Stage, fragmentalis Zone; Beroun, Kosov Quarry, section 783; uppermost part of the Kopanina Formation, a bed just below the base of the Př́idolí Series; A, C - NM-L 46535, lateral view (A) and a part of phragmocone, ventrolateral view (C), colour pattern in the form of distinct dark-grey area (arrow) and irregular patches preserved ventrolaterally (small arrow; ps - pigmented spot, us - unpigmented spot), notice also distinct muscle scars (buttress) on the base of the body chamber, margins of annular elevation indicated by arrows; B - NM-L 59873, lateral view, colour pattern in the form of rather irregular zig-zag bands preserved dextrally on the body chamber and adjacent part of the phragmocone; D, E - NM-L 46536, ventral (D) and ventrolateral (E) views, zig-zag bands running obliquely to growth lines (arrows) on adapertural part of phragmocone and adjacent part of body chamber; F, G - NM-L 46534, lateral view (F) and detail of colour pattern (G), the most distinct zig-zag band seen laterally and ventrally near the base of the body chamber; in the adapertural direction the bends are narrower and less distinct (arrows). Colour bands $\left(1^{\text {st }}-5^{\text {th }}\right)$ are numbered in the adapical direction starting close to the shell aperture. Scale bars equal $10 \mathrm{~mm}$.

NM-L 46535, 46536 (both leg. Š. Manda), NM-L 59873 (leg. L. Zedník); Ludlow Series, uppermost Ludfordian Stage, fragmentalis Zone; Beroun, Kosov Quarry, section 783 (Kř́ž 1992), bed no. 39 (Vokáč 1999); uppermost part of the Kopanina Formation, form an about $10 \mathrm{~cm}$ thick bed of rusty cephalopod pack-grainstone just below the base of the Př́ídolí Series; the cephalopod limestone overlays a light-grey brachiopod-trilobite-cephalopod grainstone yielding the Prionopeltis archiaci-Atrypoidea modesta Community (Havlíček \& Štorch 1990).

Description. - All specimens of $R$. forbesi, which bear colour patterns, are relatively large (max. reconstructed shell length about $90 \mathrm{~mm}$ ), moderately curved, moderately 

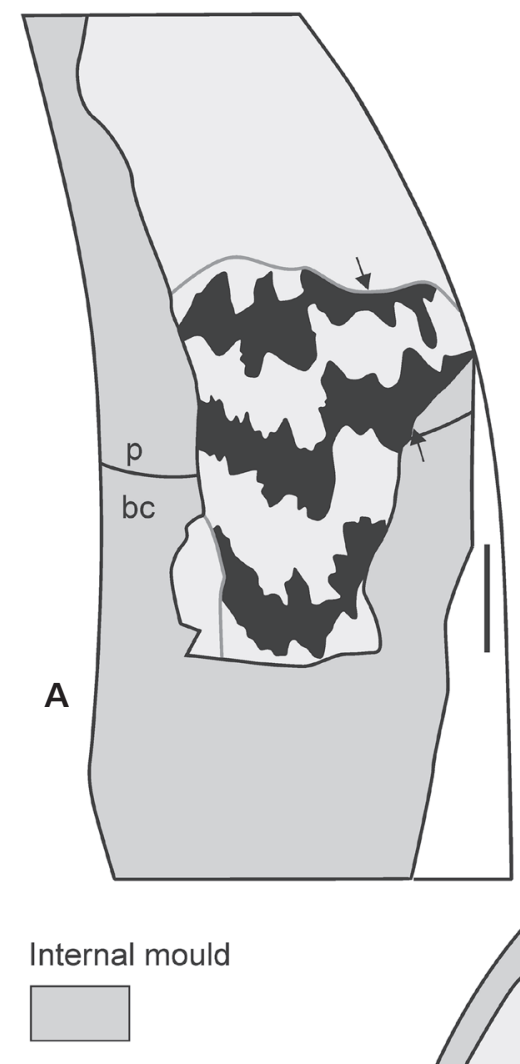

Shell preserved

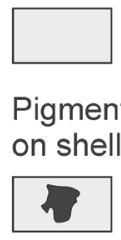

Line indicating colour preservation area

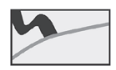

Shell, colouration covered by rocks

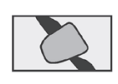

End of coloured zone preservational or natural
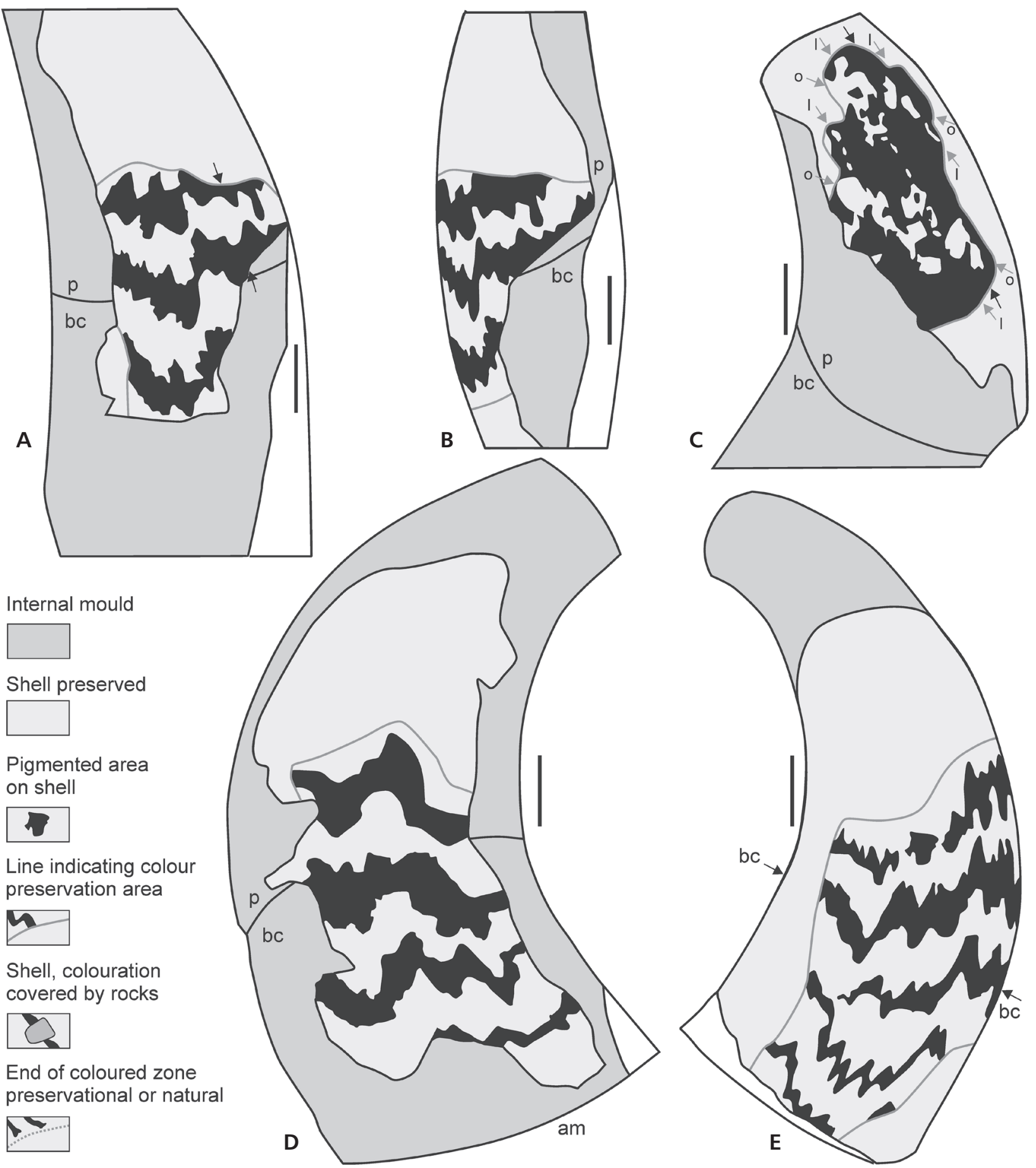

Figure 2. Schematic outlines of colour pattern in Richardsonoceras forbesi (Barrande, 1866). Specimens illustrated herein in the Fig. 1; A, B - NM-L 46536, ventrolateral (A) and ventral (B) views; C - NM-L 46535, lateral view; D - NM-L 59873, lateral view; E - NM-L 46534, lateral view. Black arrow indicates ventral axis, dark grey arrows indicate narrow longitudinal (1) and oblique (o) zones with developed patches of coloured or uncoloured shell surface. Abbreviations: am - apertural margin; bc - body chamber; $\mathrm{p}$ - phragmocone. Scale bars equal $10 \mathrm{~mm}$.

to rapidly expanding $\left(\mathrm{ae}=18-23^{\circ}\right)$, exogastrically coiled and slightly compressed, with a short body chamber, approximately corresponding to shell height. Cross section of the shell is in shape slightly narrower ventrally than dorsally. Sculpture consists of fine growth lines forming a shallow and wide hyponomic sinus. Annular elevation displays a distinct buttress; its width gradually increases from the dorsum to the venter. All four studied specimens 
are similar in size and probably represent adult individuals as indicated by the increasing shell thickness (up to $0.9 \mathrm{~mm}$ ) close to the aperture and a slight apertural constriction.

The colour pattern in specimen NM-L 46534 (Figs 1F, G; 2E) was briefly discussed by Turek (1990). The specimen is an incomplete shell with the adapical part of the phragmocone broken off; $\mathrm{sl}=86 \mathrm{~mm}, \mathrm{sh}=36.4 \mathrm{~mm}, \mathrm{sh} / \mathrm{sw}=$ 1.2 (measured in the adapertural part of phragmocone due to weathering of lateral side). Apertural margin is preserved only ventrally, it is broken laterally and dorsally. Due to deep weathering of the specimen dextrally, the colour pattern is preserved only sinistrally and ventrally, both on the body chamber and the adjacent part of phragmocone. The colour pattern is composed of irregular oblique zig-zag bands across the shell. Five colour bands are discernible in this specimen. The coloration consists of brownish bands and is the most intense on the base of the body chamber and adjacent phragmocone chambers. With the exception of the zig-zag bands, the general course of the colour bands roughly follows to the oblique course of growth lines. The fifth band (located most adapically) is interrupted two times laterally while the previous four bands are continuous. The widest colour band $(3.5 \mathrm{~mm})$ is present near the base of the body chamber. Unpigmented zones between the individual bands are here markedly wider than the pigmented zones located adapically and adaperturally of this band. The coloration of the neighbouring adapical band is less intense and the band is narrower. Traces of the sixth and seventh discontinuous bands are hardly discernible and subsequently, the colour pattern completely vanishes due to unfavourable preservation. Two narrow zig-zag bands are visible laterally on the adapertural half of body chamber. Their general course differs from preceding bands forming a deep lateral saddle. The bands approach each other ventrally due to the coiling. Intensity of coloration of the two bands situated near the aperture is lower in comparison to earlier bands. This may be a primary feature but decreased brightness of coloration adaperturally, but it is at least partially caused by poorer preservation of the shell. Mid-dorsal relicts of colour bands document the original coloration of the entire circumference of the shell.

Specimen NM-L 59873 (Figs 1B, 2D) is incomplete, strongly damaged sinistrally, $\mathrm{sl}=76 \mathrm{~mm}, \mathrm{sh}=34 \mathrm{~mm}$, and $\mathrm{sh} / \mathrm{sw}=1.2$. Colour pattern relicts are displayed dextrally on the body chamber and the adjacent part of the phragmocone. Four dark grey, oblique irregular zig-zag bands attain the maximum width of $5.3 \mathrm{~mm}$ ventrolaterally. The width of the bands decreases towards the aperture. Traces of a narrower last band are discernible dorsolaterally close to the aperture. The bands are separated by a slightly wider unpigmented zone.

Specimen NM-L 46535 (Figs 1A, C; 2C) is an internal mould with relicts of the shell wall on the phragmocone and distinct muscle scars around the base of the body chamber; $\mathrm{sl}=80 \mathrm{~mm}, \mathrm{sh}=39 \mathrm{~mm}, \mathrm{sh} / \mathrm{sw}=1.2$. Dark-grey pigmented zones displayed ventrally and ventrolaterally show a somewhat irregular colour pattern. It forms a transitional type between irregular zig-zag bands and minute isolated patches both within (unpigmented zones) and outside the bands (pigmented zones). Patches are concentrated in three narrow longitudinal zones and two poorly visible transversal zones (Fig. 2C).

Specimen NM-L 46536 (Figs 1D, E; 2A, B) is an incomplete shell with the apical part of the phragmocone broken off. The body chamber is sinistrally and ventrally strongly damaged ( $\mathrm{sl}=73 \mathrm{~mm}$, sh at the base of body chamber is $30.6 \mathrm{~mm}, \mathrm{sh} / \mathrm{sw}=1.15$ ). The colour pattern shows three irregular zig-zag bands ventrolaterally and ventrally on the body chamber and the adjacent part of the phragmocone. The bands run obliquely to the growth lines in this part of the shell; the maximum width of the bands is $7 \mathrm{~mm}$. They are markedly bilaterally asymmetrical on the venter.

Remarks. - Shell shape, angle of expansion, length of the body chamber, cross section, slightly contracted aperture in fully grown specimens, position of the siphuncle and its diameter, and sculpture of the studied specimens correspond well to the morphology of the holotype of Cyrtoceras forbesi Barrande, 1866 (pl. 115, figs 1-7). The holotype was found at Dlauha Hora $\mathrm{e}_{2}$ locality. This is the area of the Dlouhá Hora Hill in the proximity to the present day Kosov Quarry, where all specimens described herein were discovered. Classification of this species to the genus Richardsonoceras Foerste, 1933 supports the view of Dzik (1984) who assigned the species "Cyrtoceras" haueri Barrande, 1866 and other species described by Barrande (1866-1877) possessing similar morphology to this genus. Richardsonoceras forbesi co-occurs in the Kosov 783 section together with the type species of the genus Oonoceras $-O$. acinaces (Barrande, 1866) $[=O$. sociale (Barrande, 1866)].

\section{Richardsonoceras fraternum (Barrande, 1866) Figure 3B-D}

Material. - Specimen NM-L 46537; Kosoř, exact site unknown, most probably an old collector pit close to the Hvíždalka section in the Radotín Valley in the southern part of Prague (Kř́žž et al. 1986); the locality exposes the interval from the upper Ludlow (Ludfordian Stage) to the lowermost Prrídolí Series; Kopanina Formation. Based on recently collected specimens, the species $R$. fraternum occurs in the Ludlow Series, uppermost Ludfordian Stage, latilobus-balticus and fragmentalis biozones.

Description. - The shell of a single specimen of $O$. fraternum with colour pattern is relatively large $(\mathrm{sl}=69 \mathrm{~mm}$, 


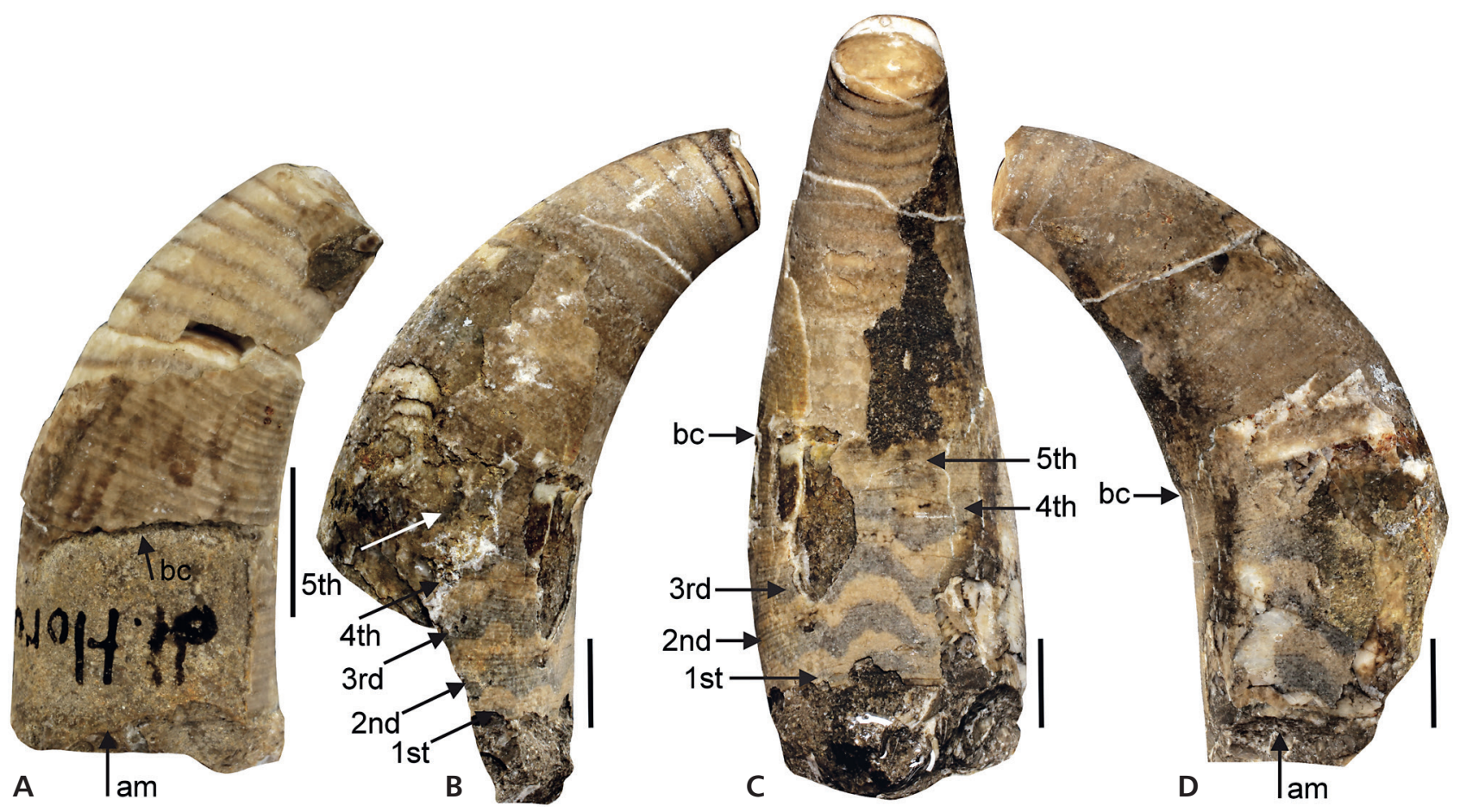

Figure 3. A - Oonoceras sp. A; NM-L 46538, Ludlow Series, Ludfordian Stage; Beroun, Dlouhá hora; Kopanina Formation; lateral view; colour pattern in form of narrow zig-zag bands on the adapertural part of the phragmocone. • B-D - Richardsonoceras fraternum (Barrande, 1866); NM-L 46537; uppermost Ludlow or lowermost Přídolí series; Praha-Kosoř; Kopanina Formation; dextral (B), dorsal (C) and sinistral (D) views; five broad colour bands visible on body chamber (indicated by arrows). For abbreviations see Fig. 2. Scale bars equal $10 \mathrm{~mm}$.

$\mathrm{sh}=c .31 \mathrm{~mm}, \mathrm{bcl}=35 \mathrm{~mm}$, moderately curved shell, moderately expanding, ae $=19^{\circ}$ ), exogastric and has an almost circular cross section $(\mathrm{sh} / \mathrm{sw}=1)$. Cross section of the shell is slightly narrower ventrally. The shell surface is smooth with fine growth lines forming a shallow hyponomic sinus. The specimen is incomplete; the adapical part of the phragmocone and the body chamber are broken off ventrally. The colour pattern is well discernible on the dorsum and flanks of the body chamber; traces of the colour pattern are observable also dorsally on the adjacent part of the phragmocone.

Five dark-grey zig-zag bands generally follow the growth line course. The bands are widely V-shaped mid-dorsally. The median tip of this "V" is directed adapically. The bands pass into smaller and narrower "V" dorsolaterally and continue in wide parabolic arches. Zigzag bands in a small amplitude follow this. The bands are almost of the same width dorsally $(3 \mathrm{~mm})$; laterally they attain the width of $4 \mathrm{~mm}$.

Remarks. - Shell morphology of the specimen with colour pattern discussed here corresponds to those of both syntypes of Cyrtoceras fraternum (Barrande 1866, pl. 109, figs 22-27). The species is assigned here to the genus Richardsonoceras. The species $R$. fraternum has a slightly broader, less curved and smaller shell than $R$. forbes $i$
(Barrande, 1866). Other morphological characters indicate close relationships between both species (Manda \& Turek 2009b), which are known from the uppermost Ludfordian Stage, Kopanina Formation of the Prague Synform sections. $R$. forbesi, however, appears stratigraphically slightly earlier that $R$. fraternum and is more abundant in the lightcoloured cephalopod limestones, while $R$. fraternum occurs in more off-shore, distal dark-grey cephalopod limestone (own field data).

\section{Oonoceras sp. A}

Figures 3A, 5A

Material. - One specimen NM-L46538 from Beroun, Dlouhá hora (locality indicates Barrande's inscription "dl. Hora" on the body chamber), i.e. the area of Dlouhá hora Hill near Kosov Quarry. The light-grey skeletal limestone in which it is preserved corresponds to the upper part of the Kopanina Formation, late Ludlow Series (Ludfordian Stage) in age. The specimen was found by V.T. during the revision of Barrande's material and was not illustrated before.

Description. - The specimen of Oonoceras sp. A has a moderately curved, rapidly expanding $\left(\mathrm{ae}=22^{\circ}\right)$ exogastric shell with a short body chamber; the shell is compressed with an elliptic cross section, which is narrower ventrally than 
dorsally $(\mathrm{sh} / \mathrm{sw}=1.3)$; the sculpture consists of distinct, transverse growth lines. Hyponomic sinus is very shallow and rounded; $\mathrm{sl}=40 \mathrm{~mm}, \mathrm{sh}=18 \mathrm{~mm}, \mathrm{bcl}=15 \mathrm{~mm}$.

The specimen is an internal mould with the shell preserved in the adapertural part of phragmocone. The colour pattern is displayed only dextrally. Zig-zag bands with great amplitudes (reaching maximum $2 / 3$ of sl) and sharp angles can be followed from the mid-dorsal to midventral region. The maximum width of colour bands is about one millimetre. The distance between individual bands roughly corresponds to their width. Two adjacent bands are connected ventrolaterally by a narrow, darkly pigmented zone.

Remarks. - Shell shape, cross section, expansion rate, body chamber length and siphuncle position corresponds to the diagnostic characters of Oonoceras Hyatt, 1884. The small size (reconstructed shell length is $45 \mathrm{~mm}$ ) and widely spaced growth lines near the aperture indicate that the shell may represent an early growth stage. Fragmentary preservation of the studied specimen limited species identification; however, the morphology of the specimen suggested a close affinity to the type species of Oonoceras O. acinaces (Barrande, 1866).

\section{Oonoceras geinitzi (Barrande, 1866)}

Figures 4, 5B

Material. - Two specimens NM-L 46539, 46540 (leg. L. Zedník); lowermost Př́ídolí Series, ultimus-parultimus Zone, Kopanina Formation, Praha-Lochkov, U topolů section (Manda \& Turek 2009b, fig. 1).

Description. - The two specimens are curved shells of moderate sizes (max. reconstructed $\mathrm{sl}=c .70 \mathrm{~mm}$ in NM-L 46539). They are exogastric, with a moderate to large ae $=$ $19-21^{\circ}$ and slightly compressed; the body chamber is very short. Distinct growth lines display a very shallow hyponomic sinus. Both specimens are almost of the same size. Slight expansions of the internal mould near the apertural margin (NM-L 46539) indicates a reduced shell thickness and thus a possible subadult to adult growth stage.

Specimen NM-L 46539 (Fig. 4C, D) represents a body chamber with about $2 / 3$ of the phragmocone; $\mathrm{sl}=62 \mathrm{~mm}$, $\mathrm{sh}=19 \mathrm{~mm}, \mathrm{bcl}=$ is $22 \mathrm{~mm}, \mathrm{sh} / \mathrm{sw}=1.3$. The shell wall is preserved on the phragmocone; the specimen is weathered sinistrally. The faint colour pattern is visible dextrally and ventrally. The typical irregular zig-zag pattern is most distinct ventrolaterally. The general course of colour bands corresponds to the course of growth lines. Close to the centre of dorsum and flanks, colour bands are indistinct. Close to the midflanks, the colour bands reach their maximum amplitude with tips directed adapically. Dark bands are narrower than the unpigmented zones.
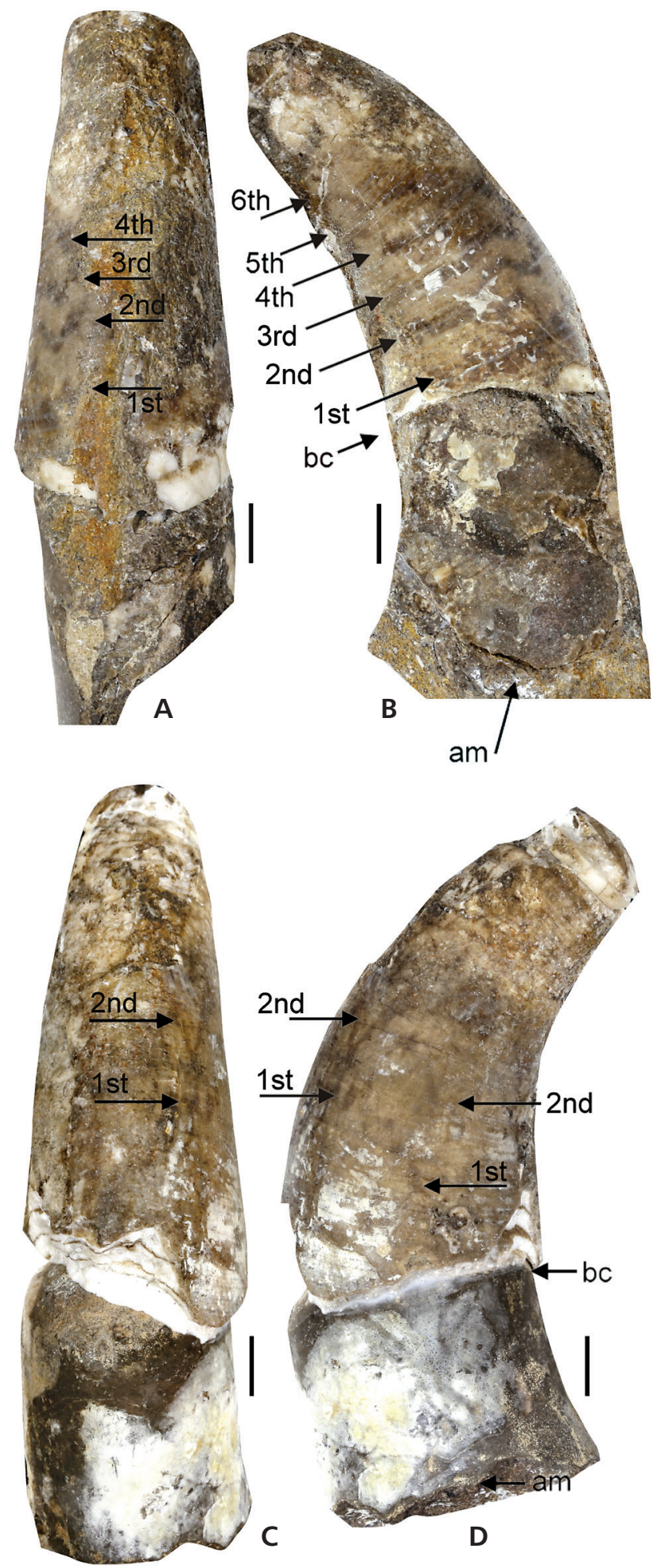

Figure 4. A-D-Oonoceras geinitzi (Barrande, 1866), lowermost Př́ídolí Series, parultimus-ultimus Zone, Praha-Lochkov, U topolů section, Kopanina Formation; A, B - NM-L 46540, ventral (A) and lateral (B) views, zig-zag bands (arrows) in the adapertural part of the phragmocone; C, D - NM-L 46539, ventral (C) and lateral (D) views. Narrow zig-zag colour bands indicated by arrows $1^{\text {st }}-6^{\text {th }}$. For abbreviations see Fig. 2 . Scale bars equal $5 \mathrm{~mm}$. 


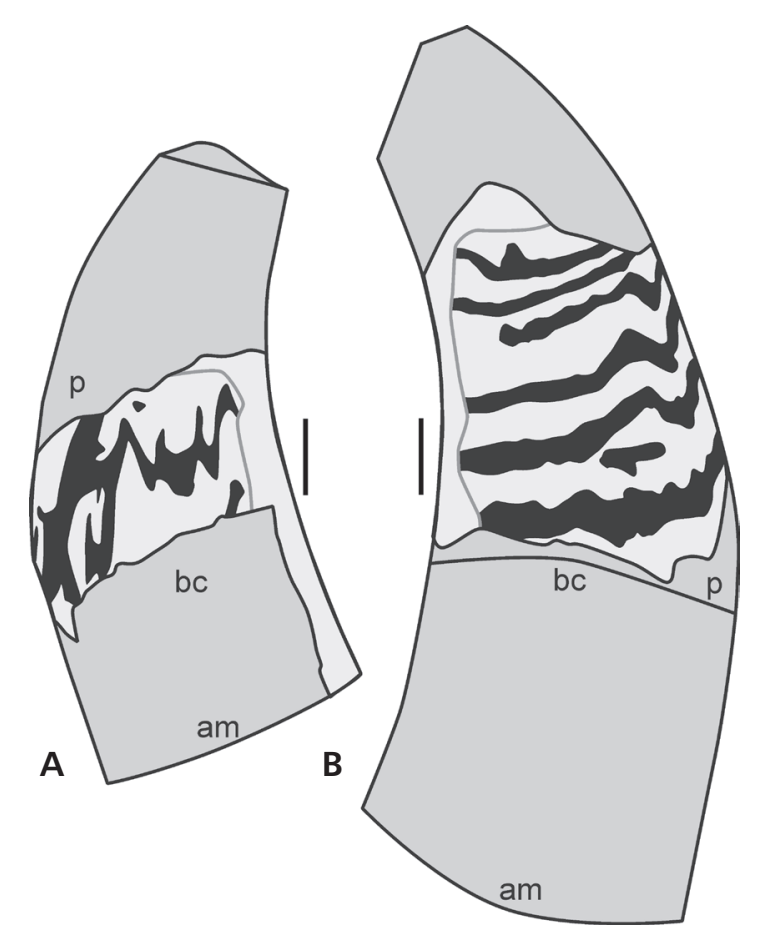

Figure 5. Schematic outlines of colour patterns in Oonoceras; lateral views. • A - Oonoceras sp. A; NM-L 46538, specimen illustrated herein in the Fig. 3A. - B - Oonoceras geinitzi (Barrande, 1866); NM-L 46540, specimen illustrated herein in the Fig. 4B. For abbreviations see Fig. 2. Scale bars equal $5 \mathrm{~mm}$.

Specimen NM-L 46540 (Fig. 4A, B) is a $63 \mathrm{~mm}$ long shell fragment with $\mathrm{sh}=24 \mathrm{~mm}, \mathrm{sh} / \mathrm{sw}$ at the base of body chamber is $2.4, \mathrm{bcl}=26 \mathrm{~mm}$. The apical part is missing. The shell wall is exfoliated on the body chamber. The colour pattern is displayed sinistrally on the phragmocone. Rather narrow irregular zig-zag bands about $1.5 \mathrm{~mm}$ in width increase in amplitude from the dorsum to the venter. Near the median plane, these bands disappear. Their general course is roughly transversal. Light grey interspaces between individual bands are two to three times wider than the bands.

Remarks. - The shell shape, cross section, length of the body chamber and position of the siphuncle conforms to the diagnostic characters of Oonoceras Hyatt, 1884. The angle of shell expansion, mode of shell curvature and sculpture corresponds to that of the type material of $O$. geinitzi (see Barrande, 1866, pl. 122, figs 1-8, pl. 208, figs 31-34; Kozořz and Lochkov localities).

\section{?Oonoceras impatiens (Barrande, 1866)}

Figures 6,7

Material. - Specimen NM-L 46541; Praha-Lochkov, U topolů section; Př́́dolí Series, ultimus-parultimus Zone, a bed of dark grey cephalopod limestone (packstone) just above the base of the Prrídolí Series (leg. Š. Manda); Kopanina Formation (Manda \& Turek 2009b, fig. 1).

Description. - The shell is relatively small (reconstructed $\mathrm{sl}=c .49 \mathrm{~mm})$, slightly curved, rapidly expanding $\left(\mathrm{ae}=26^{\circ}\right)$, ventral side more convex than the dorsal side, moderately compressed and exogastric. The shell surface shows distinct transverse growth lines and moderately raised ridges. Hyponomic sinus is very slightly indicated.

Specimen NM-L 46541 (Figs 6, 7) is an incomplete shell with missing adapical part of the phragmocone; shell wall on the body chamber is exfoliated. $\mathrm{sl}=42 \mathrm{~mm}, \mathrm{sh}=21 \mathrm{~mm}$, $\mathrm{sw}=17.3 \mathrm{~mm}, \mathrm{lbc}=16 \mathrm{~mm}, \mathrm{sh} / \mathrm{sw}=1.22$, ae markedly increase during ontogeny $\left(23-32^{\circ}\right)$. Slight expansion of the body chamber close to the apertural margin may indicate a subadult growth stage of the specimen. Colour patterns are preserved around the entire circumference of the phragmocone. However, the left side of the shell is partly covered by rock. The colour pattern is peculiar and shows sudden changes in its general character. The colour bands are somewhat fragmented with light coloured patches occurring inside dark bands and with narrow bands connecting adjacent bands. The zig-zag pattern is suppressed, and the general course of pigmented zones is transverse. Short and wide transverse pigmented zones are interconnected via thin, finger-like junctions. These thin and short strips are arranged in rows running subparallel to the longitudinal shell axes. Adaperturally, the colour pattern displays a striking asymmetry, especially on the dorsum. Close to midflank, the pigmented zone is reduced into narrow strips, which are either interconnected with wide pigmented zones, or isolated. Discontinuous, wide bands are widely $\mathrm{W}$-shaped ventrally.

Remarks. - The cross section with a rounded venter, the thin, subventral siphuncle, elaborated growth lines forming slightly elevated ridges in our specimen are characteristic for Oonoceras. By contrast, it differs from Oonoceras in having a less curved and a more rapidly expanding shell; the shell curvature decreases adapically. Its shell morphology largely corresponds to "Cyrtoceras" impatiens Barrande, 1866 (Barrande 1866, pl. 120, figs 24-29).

\section{?Oonoceras aff. impatiens (Barrande, 1866)}

Figures 8, 9

Material. - Specimen NM-L 46542; Praha-Lochkov, U topolů section; Př́́dolí Series, ultimus-parultimus Zone, a bed of dark grey cephalopod limestone (packstone) just above the base of the Př́idolí Series (leg. Š. Manda); Kopanina Formation (Manda \& Turek 2009b, fig. 1).

Description. - Specimen NM-L 46542 (Figs 8, 9) represents an adapertural part of a phragmocone partly embedded 

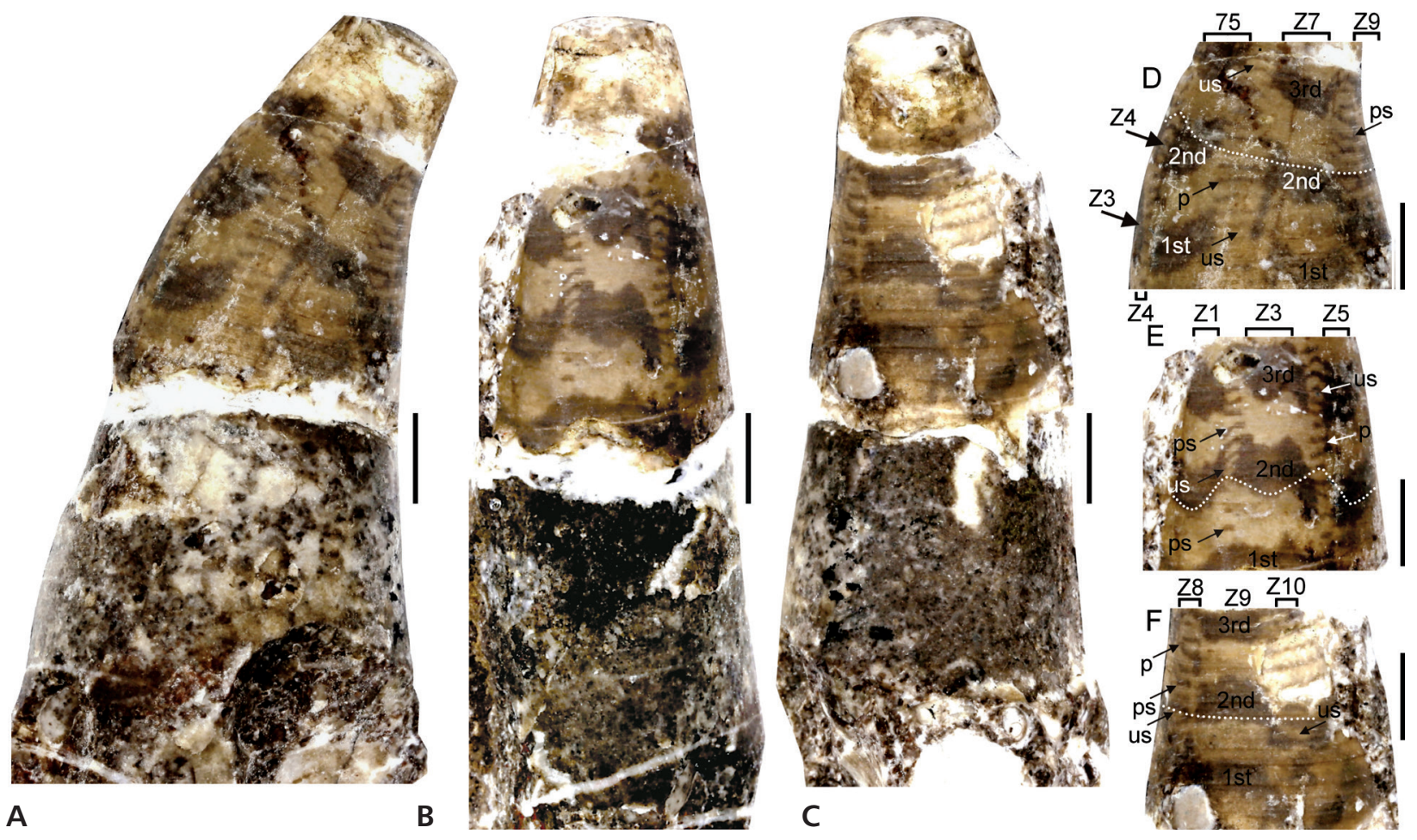

Figure 6. ?Oonoceras impatiens (Barrande, 1866); NM-L 46541; lowermost Př́́dolí Series, parultimus-ultimus Zone; Praha-Lochkov, U topolů section; Kopanina Formation; lateral (A, detail D), ventral (B, detail E) and dorsal (C, detail F) views; notice unusual colour pattern: wide zig-zags bands $\left(1^{\text {st }}-3^{\text {rd }}\right.$ in $\left.\mathrm{D}-\mathrm{F}\right)$ reduced into isolated patches arranged in narrow longitudinal zones $(\mathrm{Z} 2,4,6,8,10)$ indicated by arrow with grey letters A-E, sometimes interconnected by short narrow bands or spots. Notice also the asymmetry of the colour pattern dorsally. Abbreviations: ps - pigmented spots; us - un-pigmented spots; $\mathrm{p}$ - narrow band protrusion. Dotted line indicates the course of colour bands. Scale bars equal $5 \mathrm{~mm}$.
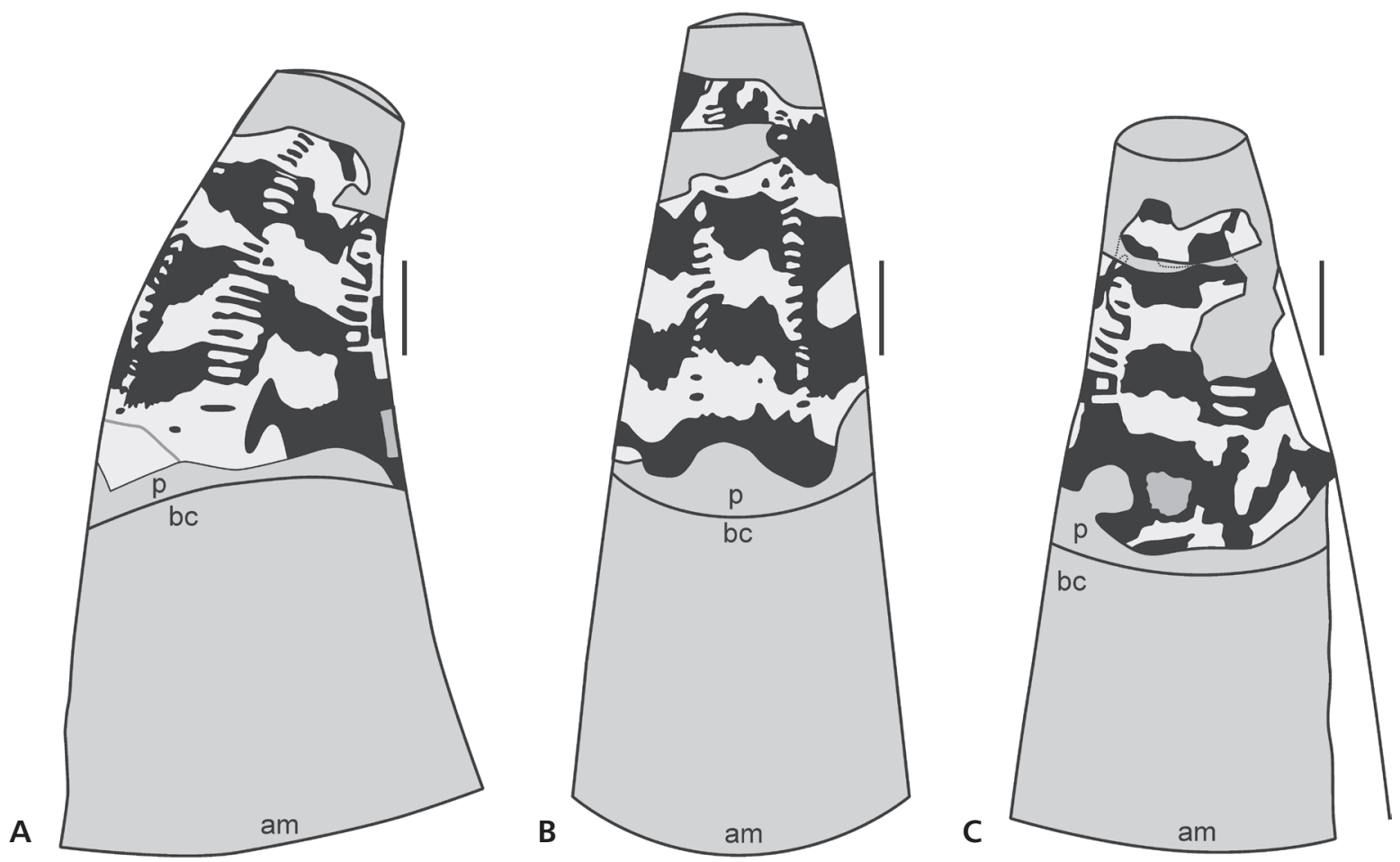

Figure 7. Schematic outlines of colour pattern in ?Oonoceras impatiens (Barrande, 1866); specimen illustrated in the Fig. 6, lateral (A), ventral (B) and dorsal (C) views. For abbreviations see Fig. 2. Scale bars equal $5 \mathrm{~mm}$. 


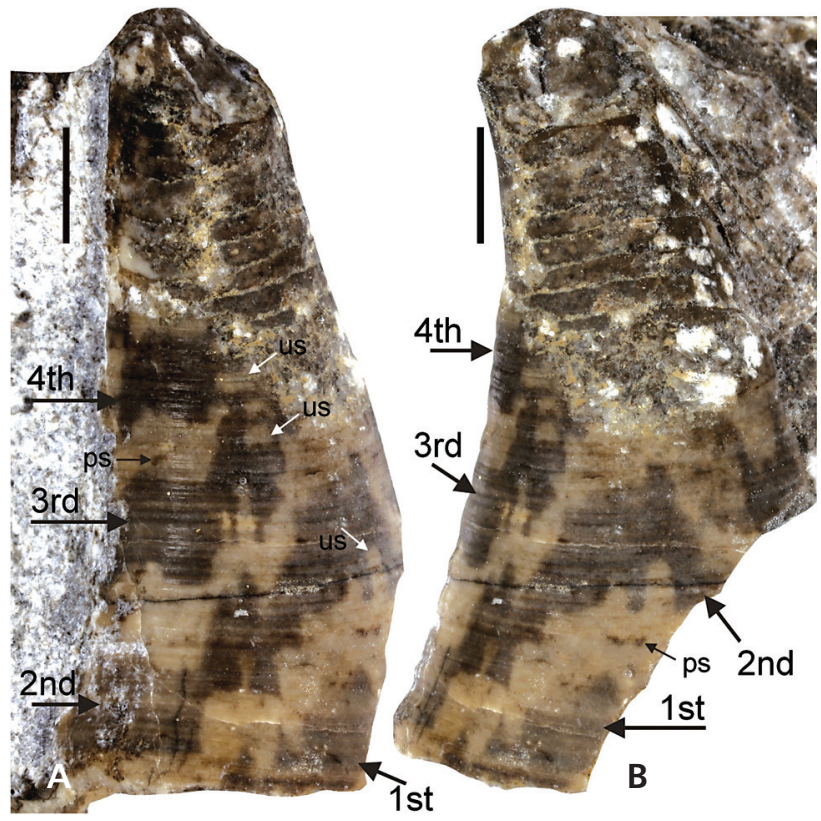

Figure 8. ?Oonoceras aff. impatiens (Barrande, 1866); NM-L 46542; lowermost Př́idolí Series, parultimus-ultimus Zone; Praha-Lochkov, $\mathrm{U}$ topolů section; Kopanina Formation; dorsal (A) and lateral (B) views; four wide zig-zags in the adapertural half of the phragmocone indicated by arrows. Abbreviation: ps - pigmented spots; us - unpigmented spots. Scale bars equal $5 \mathrm{~mm}$.

in rock. It is adapically exfoliated showing several short phragmocone chambers; $\mathrm{sl}=34 \mathrm{~mm}$ long, $\mathrm{sh}=17 \mathrm{~mm}$, ae $=30^{\circ}$. Four distinct wide colour bands are exposed dorsally and laterally. Their width changes rapidly, attaining maximum width mid-dorsally. Starting mid-dorsally, irregular zig-zags run adapically, obliquely to growth lines; near midflank, the general course of zig-zag bands change and they run obliquely adaperturally (bands thus form a V-shaped pattern). Pigmented and un-pigmented areas on the shell surface are balanced.

Remarks. - Our specimen of ?O. aff. impatiens resembles ?O. impatiens (Barrande, 1866) from which it differs, besides differences in colour pattern, in having more

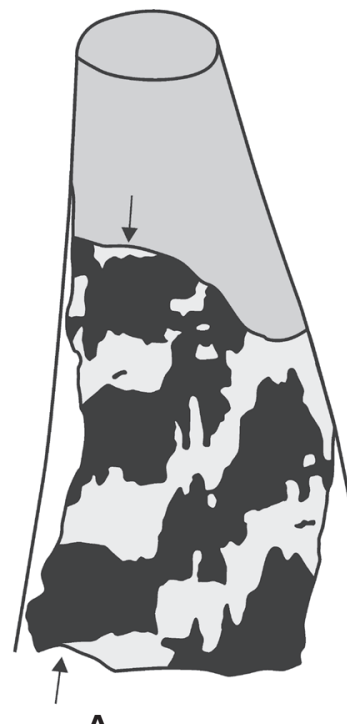

A

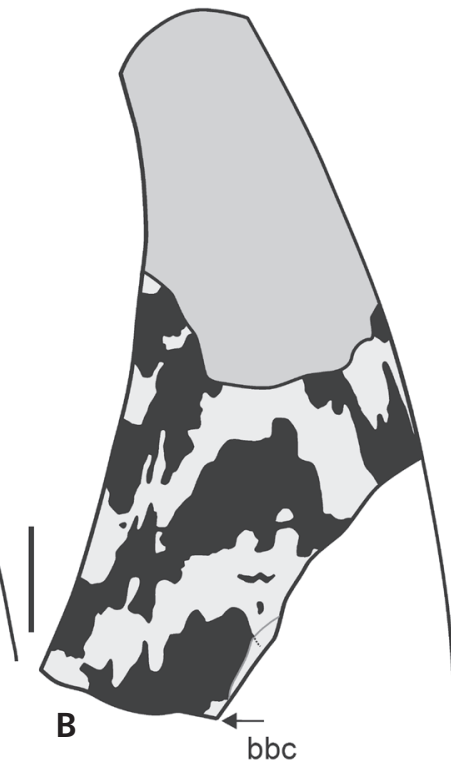

Figure 9. ?Oonoceras aff. impatiens (Barrande, 1866); schematic outlines of the colour pattern in specimen NM-L 46542 illustrated herein in the Fig. 8, dorsal (A) and lateral (B) views. Abbreviation: bbc - base of the body chamber, arrows indicate the dorsal shell axis. Scale bar equals $5 \mathrm{~mm}$.

distinct growth ridges. The only specimen available represents an incomplete phragmocone hampering a more precise taxonomic determination. Our specimen of?O. aff. impatiens was found in the same bed as ?O. impatiens; they are at least closely related or conspecific.

\section{Chromatoceras veteranum (Barrande, 1866)}

Figures 10-13

Material. - Six specimens showing colour patterns (see Tab. 2 for catalogue numbers and dimensions, for further details see systematic appendix). Barrande $(1866,1877)$ illustrated two specimens of $C$. veteranum with a preserved colour pattern. Only the venter of the holotype (NM-L

Figure 10. Chromatoceras veteranum (Barrande, 1866); A-D, K, L- NM-L 21751 (specimen, Barrande 1877, pl. 514, figs 13-17), lowermost Př́idolí Series, Praha-Lochkov, Kopanina Formation, dorsal (A, C) and lateral (B, D) views and details (K, L), a-d indicates four bands branched into narrow bands, e.g. a1-3; E, F - NM-L 10127 (holotype of “C." sica Barrande, 1866, pl. 124, figs 6-11), lowermost Př́ídolí Series, Praha-Slivenec, Kopanina Formation, lateral views; G - NM-L 46581, lowermost Př́dolí Series, parultimus-ultimus Zone, Praha-Lochkov, U topolů section, Kopanina Formation, dorsolateral view showing changes in the colouration of the juvenile shell: irregular patches (ip) - (Stage 1), V-shaped bands (vsb) - (Stage 2) and transversal band (tb) - (Stage 3); H-J, M-O - NM-L 46890; lowermost Př́́dolí Series, parultimus-ultimus Zone, Praha-Lochkov, U topolů, Kopanina Formation, lateral (H, J) and dorsal views (I) and details of adapical part of phragmocone, dextral (M), dorsal (N) and sinistral (O) views. Dotted line indicates generalized course of colour bands. Notice peculiar colour pattern - combination of longitudinal zones with densely spaced undulated transversal bands and zones with irregular broad zig-zags, sometimes partly overlapping. Abbreviations: a, b, c, d - indication of uninterrupted colour bands; $\mathrm{bb}$ - band branching; bc - band connection; bi - band interruption; bv - band vanishing; da - decreasing amplitude of V-shaped bands passing into transversal bands; $i b$ - irregular band; $o b$ - oblique band; $p$ - protruding part of the band; $p s$ - pigmented spot; $t$ - transversal band; tb - termination of the band; $\mathrm{tr}$ - patches arranged in triangular composition; $\mathrm{tt}$ - terminal thickening of the band; up - unpigmented spot; us - unpigmented spots; uz - unpigmented zone surrounded by transversal bands; vb - V-shaped band; Z1 to Z12 - short transversal irregular bands arranged into longitudinal zones. Scale bars equal $5 \mathrm{~mm}$. 
Vojtěch Turek \& Štěpán Manda • Discontinuous, asymmetric and irregular colour patterns in Silurian oncocerids with cyrtoconic shells
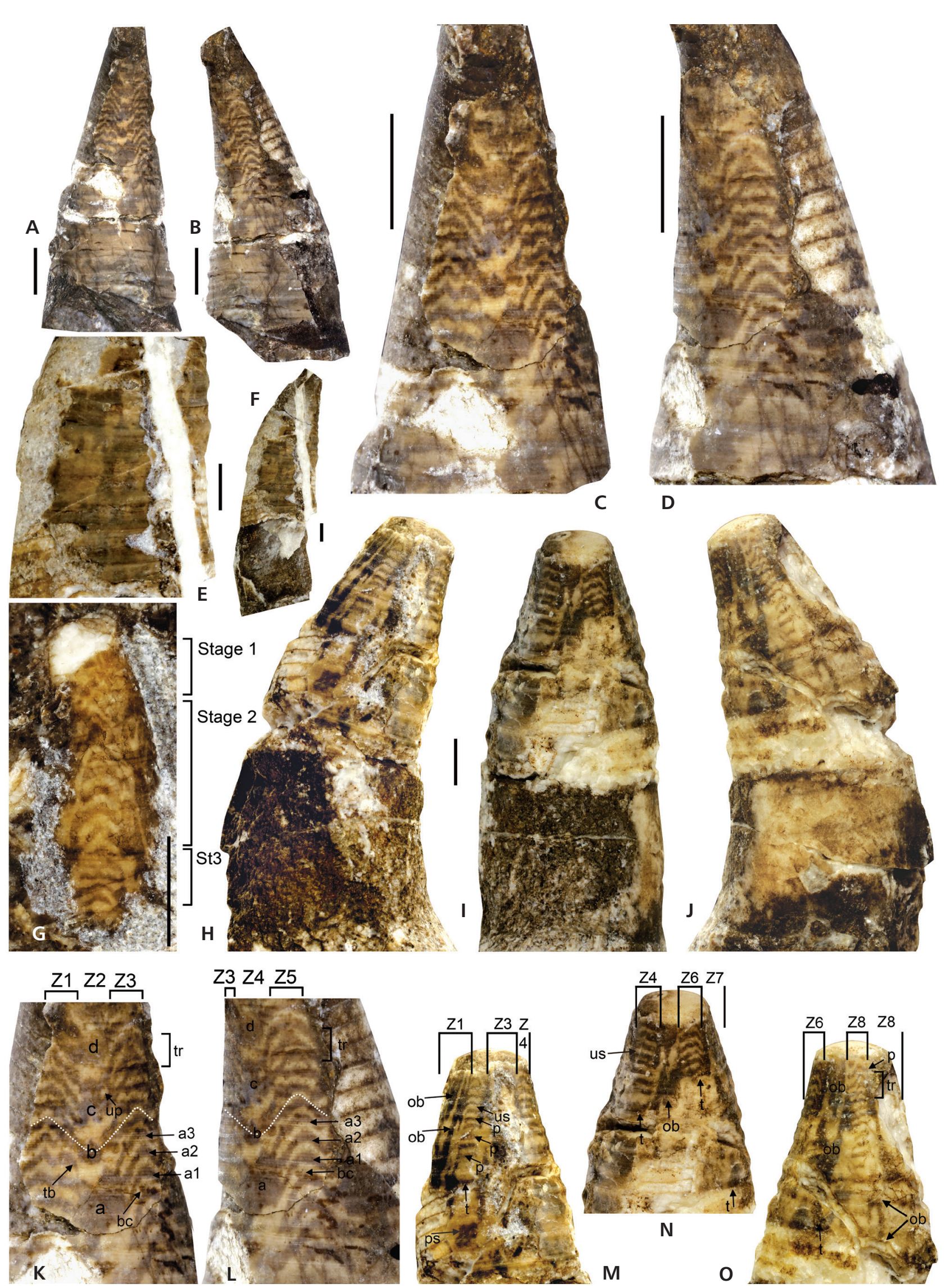
14298, Barrande 1866, pl. 208, fig. 21) was figured. Another, smaller specimen NM-L 21751 from the locality Lochkov was illustrated later (Barrande, 1877, pl. 514, figs 13-17).

Description. - The holotype (NM-L 14298; Figs 11I-P, $13 \mathrm{D}-\mathrm{G})$ is an incomplete shell with partly exfoliated shell wall (for dimensions see Tab. 2). The embryonic shell is missing. Colour pattern is preserved on the phragmocone only. Relicts of the shell wall attached to the internal mould of the body chamber are poorly preserved. The darkly pigmented zig-zag bands are well visible around the whole shell circumference. Their general course is roughly transversal, but the pattern is laterally asymmetrical and markedly changes during growth. Typical zig-zag bands are more distinct in the adapical part of the phragmocone. Adaperturally, the colour bands become serrate dorsally and resembles fragments of "seismic recordings". The bands are very narrow and usually less than one millimetre wide. Brownish colour bands are separated by slightly wider light grey interspaces indicating light colouring of the original shell.

Specimen NM-L 21751 (Figs 10A-D, K, L; 12A, B) is an almost complete, small, juvenile shell, which is missing most of its apical part (for dimensions see Tab. 2). The body chamber is ventrally broken off. The shell wall is ventrally and ventrolaterally exfoliated, adapical part of the phragmocone is ventrally abraded and shows the morphology of the siphuncle. The colour pattern is well preserved dorsally (partly also on the body chamber) and dorsolaterally. It consists of rather irregularly developed, narrow zig-zag bands. Some of them disappear middorsally while others merge into irregular patches or form a widely W-shaped pattern. Moderate asymmetry of the colour pattern is well expressed dorsally. Tips of the "W-shape" are directed adorally. Dorsolaterally, the narrow colour bands form oppositely oriented "V"s with the tips directed adapically. The mid-dorsal zone is lighter in colour than the dorsolateral part of the shell. Irregularity and asymmetry of the colour bands increase towards the body chamber; the features are well expressed dorsally. Close to the base of the body chamber, the zig-zag pattern fades out.

Specimen NM-L 46581 (Fig. 10G, 12D) is a fragment of the early juvenile part of the shell. Colour pattern is observable dorsolaterally and documents rapid changes in the course of colour bands during early ontogeny. The bands in the earliest preserved shell part are discontinuous forming more or less isolated patches. Later, the bands form zig-zag patterns with the V-shaped tips oriented adapically. On the shell fragment located most adaperturally, the zigzag pattern is suppressed.

Relicts of zig-zag bands are preserved in NM-L 10127 (Figs 10E, F and 19G, H). The almost complete specimen is, however, strongly damaged. The shell wall is partly preserved on the phragmocone and shows slightly expressed irregular zig-zag bands mid-laterally. Their tendency to coalesce into patches is indicated.

Specimen NM-L 46890 (Figs 10H-J, M-O and 13A-C) represents a complete body chamber and a phragmocone with missing adapical part; the shell wall of the body chamber is exfoliated. The colour patterns show an unusual combination of irregular transverse bands arranged into longitudinal rows and broad zig-zags. Two rows of short, thin and densely spaced bands are located dorsally and one row near the centre of the flanks. Relicts of distinct zig-zag bands with an acute angle are preserved between these rows. These bands sometimes overlap transverse bands, which disappear adapically, while zig-zag bands persist.

The heavily damaged specimen NM-L 46578 (Figs $11 \mathrm{~A}-\mathrm{H}, 12 \mathrm{C}-\mathrm{G})$ lacks the adapical part of the phragmocone and the adapertural part of the body chamber. It probably represents an incomplete subadult growth stage. Colour patterns are well visible across the entire circumference of the phragmocone. The general pattern closely resembles the pattern in specimen NM-L 21751. It shows two longitudinal rows of short transverse bands vaulted or pointed adapically on dorsum and venter. Between them, darkly pigmented patches occur. Finely serrate undulating bands running roughly transversally cover the flanks. The narrow transverse bands changed adapically from vaulted to transversal. Similar, lighter-coloured zones with patches of dark pigment, as in the centre of ventral and dorsal sides, are developed ventrolaterally and dorsolaterally.

Specimen NM-L 46580 (not figured) is incomplete with missing adapical part of the phragmocone. Relicts of the colour pattern are present dorsolaterally on the phragmocone and show dark grey zig-zag bands. However, due to poor preservation, a more detailed description of the pattern is impossible.

\section{Chromatoceras constringens (Barrande, 1866)}

Figures 14, 15, 20

Material. - Two specimens NM-L 669, 46579; for details see the systematic appendix.

Figure 11. Chromatoceras veteranum (Barrande, 1866); A-H - NM-L 46578, lowermost Př́́dolí Series, parultimus-ultimus Zone, Praha-Lochkov, U topolů, Kopanina Formation, ventral (A, E), dorsal (B, F) and lateral views (C, G and D, H), a, b, c indicate continuous individual bands; I-P - NM-L 14298 (holotype illustrated by Barrande 1866, pl. 208, fig. 21); lowermost Př́ídolí Series, Kosoř, Kopanina Formation, ventral (K, M), dorsal (I, N) and lateral views (J, O and L, P). For abbreviations see Fig. 10. Scale bars equal $5 \mathrm{~mm}$. 
Vojtěch Turek \& Štěpán Manda • Discontinuous, asymmetric and irregular colour patterns in Silurian oncocerids with cyrtoconic shells
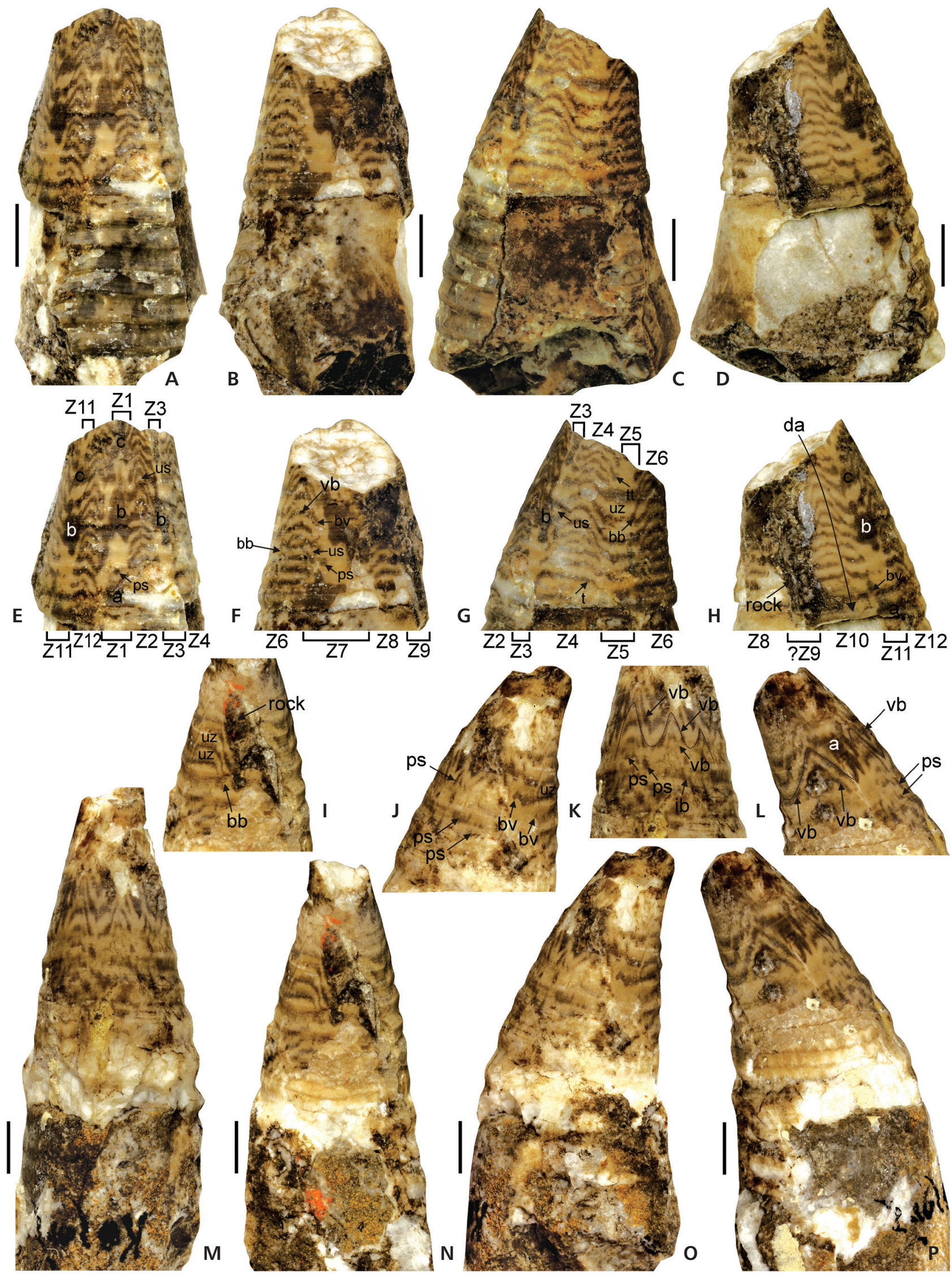

L
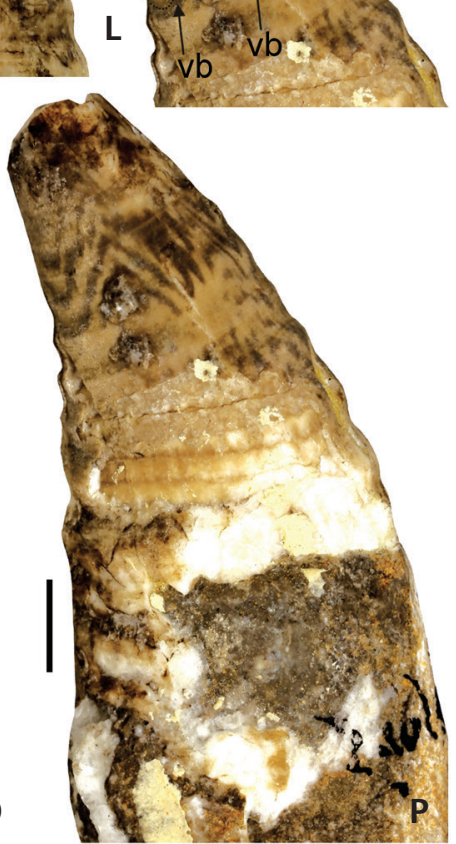
Description. - The holotype NM-L 669 is an incomplete shell missing the adapical half of the phragmocone (for dimensions see Tab. 2). The shell wall is partly exfoliated. The colour bands are partially visible around the whole circumference of the shell (Figs 14A-D, 15). Its venter shows markedly asymmetric colour patterns. Bands, generally running obliquely to the shell axis in an angle c. $20^{\circ}$, form separated segments, some of them resembling rhabdosomes of graptolites. Wide lateral strips with frayed margins indicate the general zig-zag course of the bands. Disintegrated narrow band segments of similar course as on its venter are discernible also dorsally. Between main

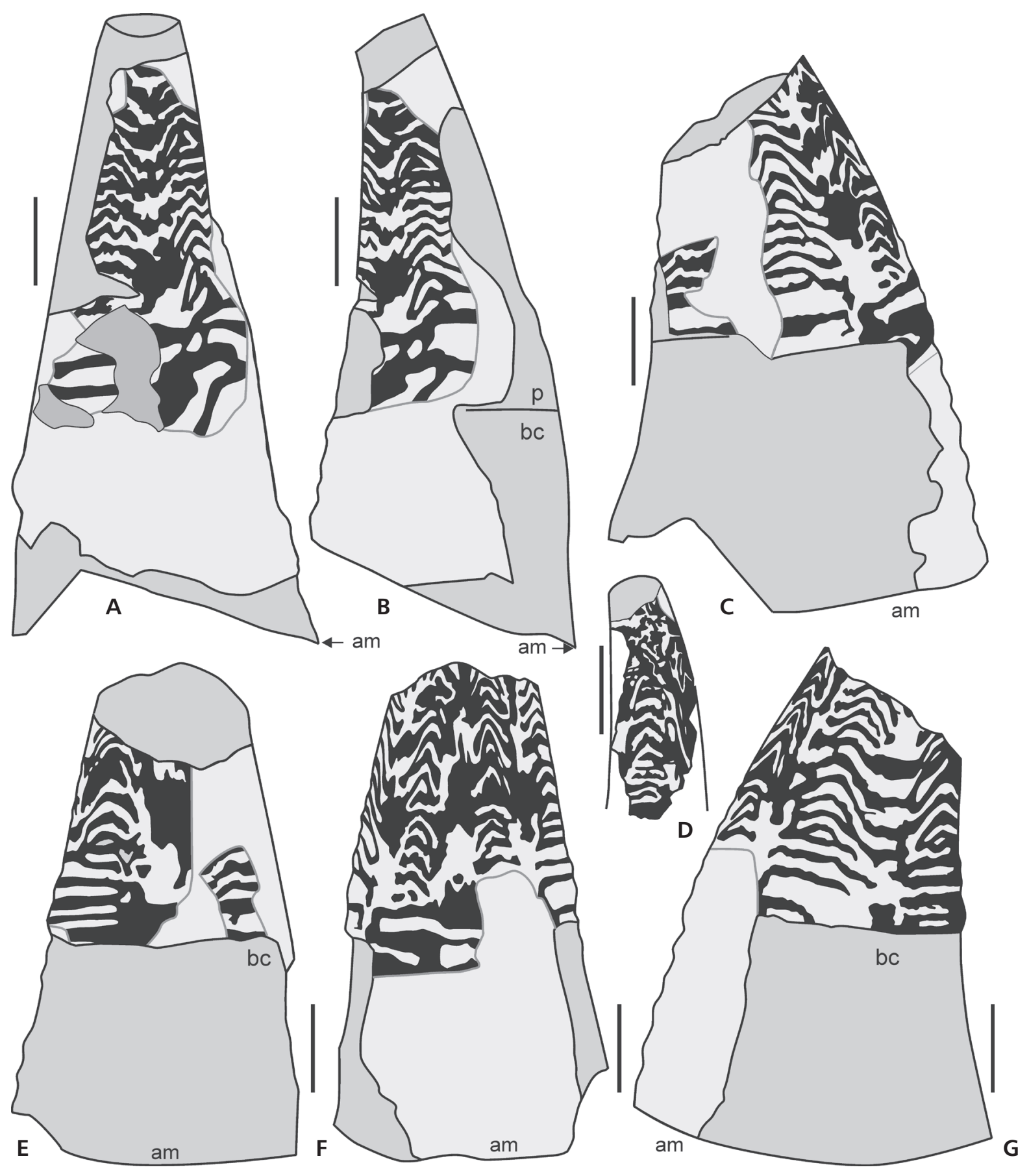

Figure 12. Schematic outlines of colour pattern in Chromatoceras veteranum (Barrande, 1866); A, B - NM-L 21751, illustrated in the Fig. 10A-D, dorsal (A) and lateral (B) views; C, E-G - NM-L 46578; illustrated in the Fig. 11A-H, lateral (C, G), dorsal (E) and ventral (F) views; D - NM-L 46581, illustrated in the Fig. 10G, dorsolateral view. For abbreviations see Fig. 2. Scale bars equal $5 \mathrm{~mm}$. 


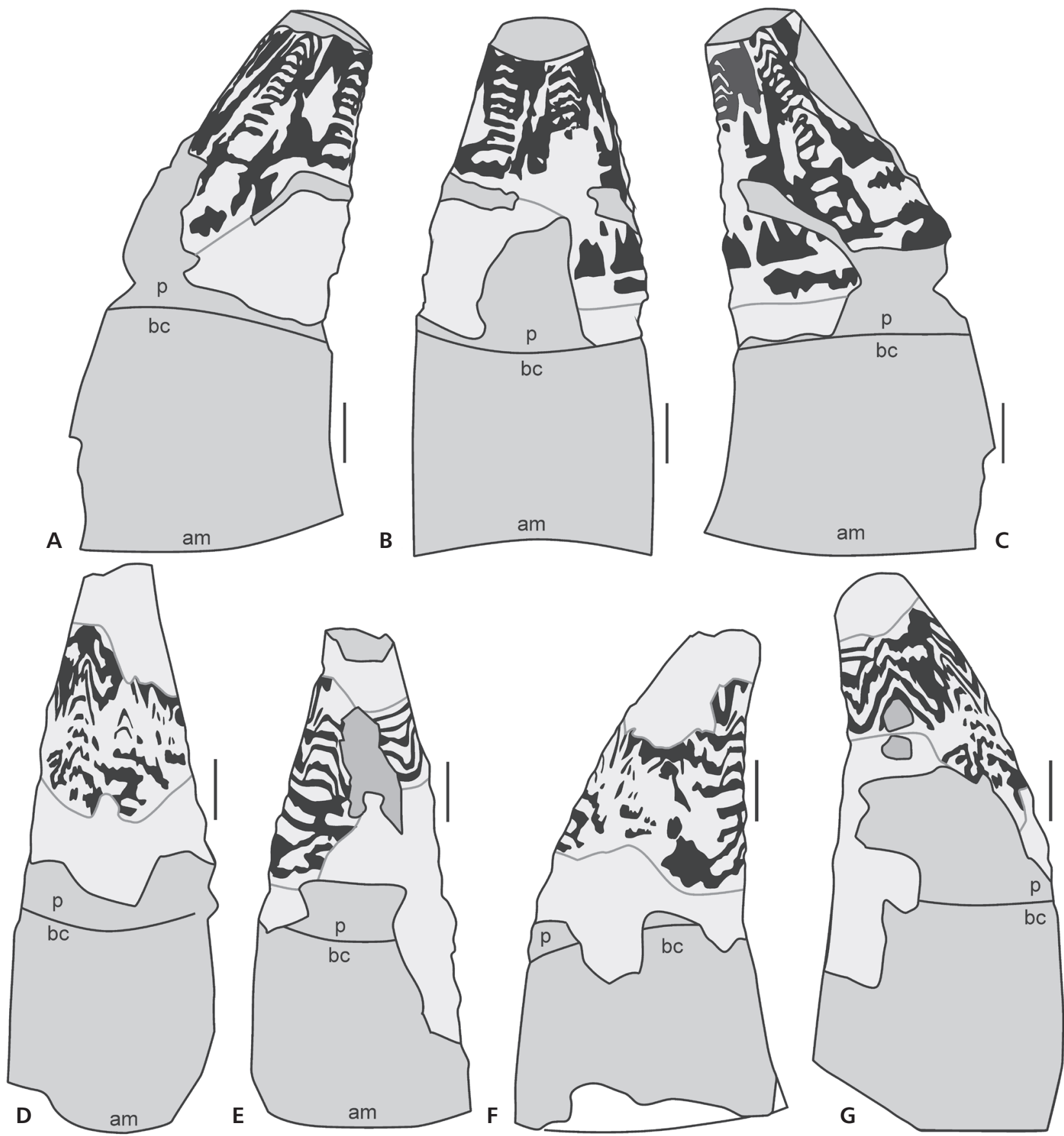

Figure 13. Schematic outlines of colour patterns in Chromatoceras veteranum (Barrande, 1866); A-C - specimen NM-L 46890, illustrated herein in the Fig. 10H-J; D-G - specimen NM-L 14298, illustrated herein in the Fig. 11I-P. For abbreviations see Fig. 2. Scale bars equal $5 \mathrm{~mm}$.

pigmented zones, small pigmented patches are located irregularly.

Specimen NM-L 46579 (Figs 14E, F; 20A-C) displays a well-preserved shell, only the left side of the body chamber is damaged. A zig-zag pattern formed by discontinuous narrow bands is discernible laterally (dextrally) on the body chamber and the adjacent part of the phragmocone.
?Euryrizoceras decurio (Barrande, 1866)

Figure 16

Material. - The species is based on the holotype (NM-L 15404) only, illustrated by Barrande (1866) in pl. 240, figs 11-14 (refigured here as Fig. 16); its preservation and sedimentary filling of the body chamber (dark grey cephalopod packstone) indicate Ludlow Series (Ludfordian 

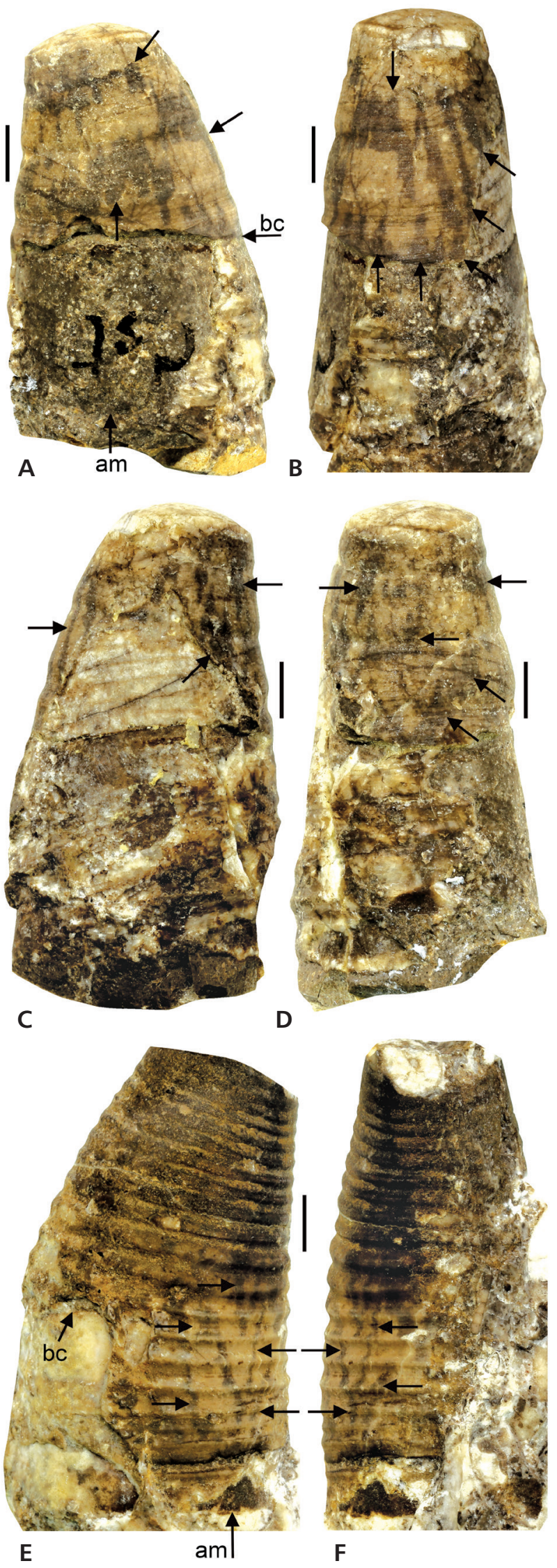

Stage, Kopanina Formation) or Př́idolí Series (Požáry Formation). The locality "Vallon de Slivenetz", i.e. Slivenec Valley near Praha-Slivenec, is given in the text and figure captions concerning this species (Barrande 1867, p. 69). Nevertheless, Barrande's original inscription "Gr. Kuchel" (= Gross Kuchel), i.e. land registry of PrahaVelká Chuchle, is written in black ink on the specimen. However, both localities lie close to each other in the Slivenec Valley but in different land registries; based on the mode of preservation, the origin from the locality "Vallon de Slivenetz" is more likely.

Description. - The shell of the holotype of ?E. decurio is small $(\mathrm{sl}=38.6 \mathrm{~mm}, \mathrm{sh}=19.4 \mathrm{~mm})$, rapidly expanding ae $=$ $22^{\circ}$ ); length of reconstructed complete shell is about $45 \mathrm{~mm}$ ), slightly curved and exogastric. Body chamber occupies $2 / 5$ of the shell length. The shell is moderately compressed, elliptic in cross section $(\mathrm{sh} / \mathrm{sw}=1.25)$. The sculpture consists of distinct, transversal growth lines forming a shallow hyponomic sinus ventrally; internal structure of the siphuncle is unknown. The specimen is incompletely preserved, with strongly damaged phragmocone and missing adapical part. The shell wall is partially preserved on the phragmocone; on the body chamber, it is exfoliated except relicts of dorsolateral shell wall.

The colour pattern is well preserved on the phragmocone dextrally and dorsolaterally (Fig. 16A). Distinct bands in the form of narrow and high parabolas are situated midlaterally (dextrally); dark-grey bands are widest near apices of these parabolas, which are oriented adaperturally. There, their width reaches three millimetres. Segments of parabolas dorsolaterally form a V dorsally, probably with a small mid-dorsal lobe. Two transversally prolonged patches of dark-grey pigment displayed sinistrally probably do not represent an original colour pattern and are rather of diagenetic origin. Sporadic traces of colour patterns are preserved ventrolaterally. They indicate that originally, the zig-zag colour pattern was present on the entire circumference of the shell. Lighter coloured interspaces are almost of the same width as the darker bands.

Remarks. - The illustration by Barrande (1866, pl. 240, fig. 11) showing wide, dark grey symmetrical V-shaped bands laterally is in this case inaccurate and simplified (see

Figure 14. Chromatoceras constringens (Barrande, 1866); A-D - NM-L 669 (holotype by monotypy, illustrated by Barrande 1866, pl. 156, figs 1-6), lowermost Př́idolí Series, Kosoř, Kopanina Formation, sinistral (A), ventral (B), dextral (C) and dorsal (D) views. Notice striking asymmetry of colour pattern on ventral side (indicated by arrows); E, F - specimen NM-L 46579 illustrated herein also in the Fig. 20A-C, lowermost Př́dolí Series, parultimus-ultimus Zone, Praha-Lochkov, U topolů section, Kopanina Formation, lateral (E), and dorsal (F) views. Abbreviation: $\mathrm{bc}$ - body chamber. Scale bars equal $5 \mathrm{~mm}$. 

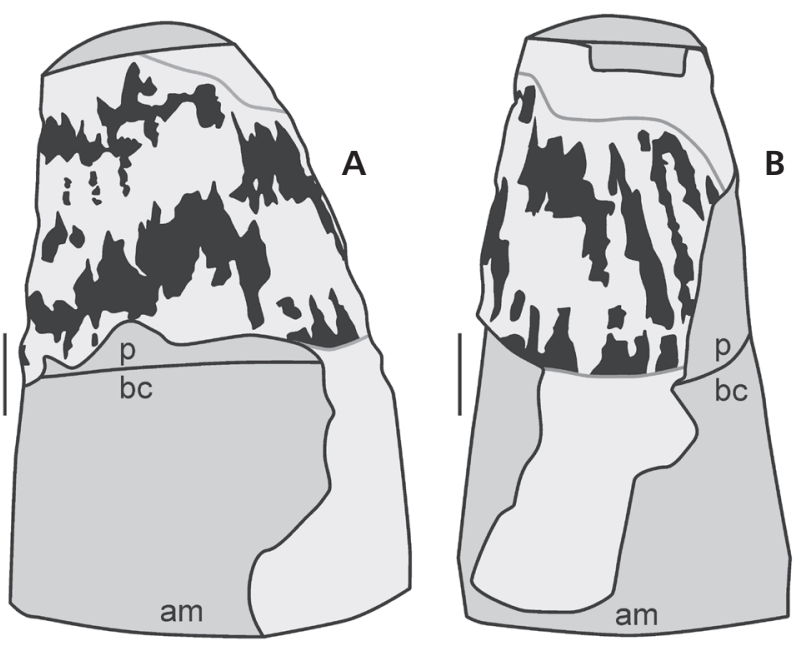

Figure 15. Schematic outlines of colour pattern in Chromatoceras constringens (Barrande, 1866); A, B - specimen NM-L 669 illustrated herein in Figs 14A, B and 20D-G, lateral (A) and ventral (B). For abbreviations see Fig. 2. Scale bars equal $5 \mathrm{~mm}$.

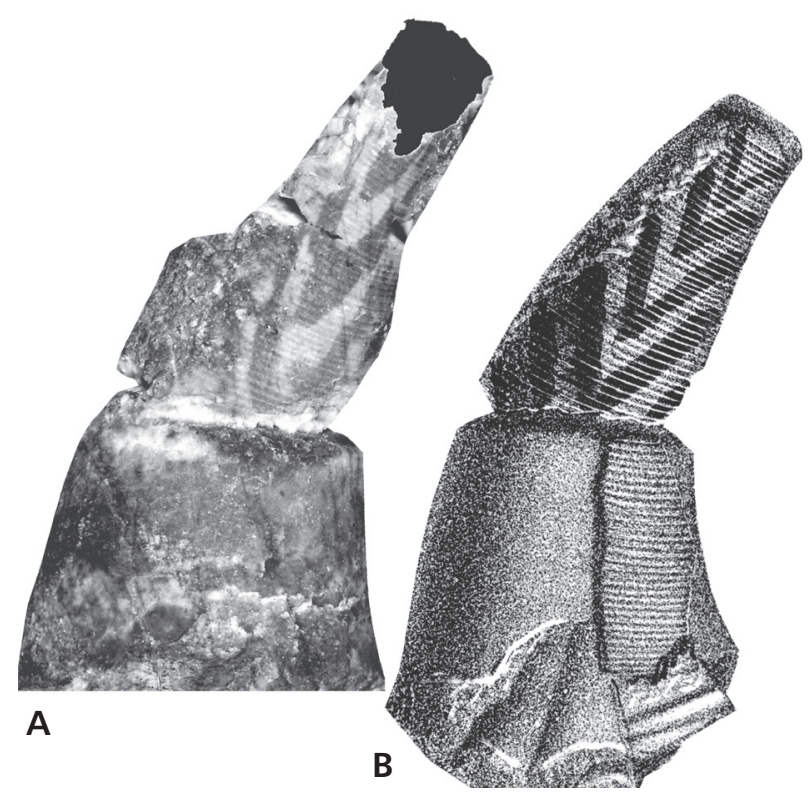

Figure 16. ?Euryrizoceras decurio (Barrande, 1866), NM-L 15404 (holotype by monotypy), upper Ludlow or lower Př́ídolí Series, PrahaSlivenec (Vallon de Slivenetz), Kopanina or Požáry Formation, lateral view. Distinct colour pattern in form of narrow parabolas situated laterally (A) and Barrande's illustration of the specimen from the year 1866, pl. 240, figs 11-14 (B). Notice strongly simplified original Barrande's illustration.

Fig. 16A, B). The character of the apertural margin and the rather constant density of growth lines on the entire body chamber indicate that the only known specimen of ?E. decurio represents very likely a juvenile growth stage, which complicates its taxonomic assignment. Nevertheless, the slightly curved, exogastric, and rapidly expanding shell and the large body chamber equal the characters of
Euryrizoceras Foerste, 1930b; Euryrizoceras obesum (Barrande, 1866) ranges in Bohemia from the middle Wenlock up to the upper Př́dolí series (Manda \& Turek 2009b).

Family Oocerinidae Teichert, 1939

\section{Oocerina aff. lentigrada (Barrande, 1866) \\ Figures 17, 18}

Material. - One single specimen NM-L 59875, Karlštejn, Budňany Rock section (Kř́iž 1992); Př́ídolí Series, transgrediens Zone, Požáry Formation, uppermost bank of cephalopod limestone just below the Silurian-Devonian boundary (Chlupáč et al. 1972; beds 40, 41 in Kř́ž 1992). The specimen was found by V. Turek in 1988 and the colour pattern was briefly discussed by Turek (1990).

Description. - The studied specimen shows the body chamber and the adjacent third of the phragmocone. The shell is a slightly curved, slowly expanding $\left(\mathrm{ae}=8^{\circ}\right)$, compressed $(\mathrm{sh} / \mathrm{sw}=1.14)$ and exogastric; its venter exhibits a faint keel. The body chamber is very short with an adapertural length of $30 \mathrm{~mm}$; the fragment has a maximum length of $68 \mathrm{~mm}$ and a maximum height of $28 \mathrm{~mm}$. The shell wall is preserved on the adapertural part of the phragmocone and in relicts also on the body chamber. The shell surface is smooth; fine growth lines form a welldeveloped, wide and moderately sharp hyponomic sinus. The annular elevation expands from the dorsum laterally, reaching the maximum width of $6.1 \mathrm{~mm}$ mid-laterally; the annular elevation is ragged.

The colour pattern is preserved along the entire circumference of the shell (Figs 17, 18). Dark grey transverse, densely spaced bands have a width about one millimetre. They are separated by light-coloured interspaces, which are almost of the same width as the colour bands, or slightly wider dorsally. Their undulation is most pronounced laterally and dorsally in the preserved adapical part of the phragmocone, the undulation is irregular, bilaterally asymmetrical in dorsal view. Ventrally, the course of colour bands corresponds to the growth lines course. Toward the aperture, the pronounced undulation diminishes dorsally and laterally, and bands become straight ventrally. The bands in the adapertural part of the phragmocone are almost straight around the entire circumference of the shell. The three most adoral bands are developed ventrally and disappear laterally.

Remarks. - The studied specimen corresponds to Oocerina Foerste, 1926 in shell shape, cross section, expansion rate, presence of a ventral keel and type of sculpture (very fine growth lines or almost smooth shell). Shell parameters of the specimen are similar to parameters of the type species of Oocerina - O. lentigrada (Barrande, 1866). This species 
is, however, documented from the uppermost Ludlow of the Prague Synform, i.e. it is stratigraphically slightly older than the above-described specimen. The Silurian species at present assigned to Oocerina are in need of a revision. This is why we describe the studied specimen in the opened nomenclature.

\section{Discussion}

\section{Colour patterns in cephalopods} with distinctive surface sculpture

Shell colour patterns in fossil cephalopods were usually described from Early Palaeozoic forms that are smooth or inconspicuously sculptured (Foerste 1930a, Teichert 1964). Ribbed shells of Palaeozoic cephalopods display shell colouration only very occasionally (Kröger 2011 Middle Ordovician endocerid Anthoceras Teichert \& Glenister, 1954; Blake 1882, Manda \& Turek 2015 - Silurian orthocerid Dawsonoceras Hyatt, 1884; Turek \& Manda 2010, 2011 - Silurian nautilid Peismoceras Hyatt, 1894). Therefore, the ribbed shell of Chromatoceras displaying colour patterns represents a rather exceptional case. This indicates that the colouring occurred in strongly ornamented oncocerids as well. Cowen et al. (1973) suggested that such a type of sculpture produced shadows that visually broke up the shell outline and functioned in an analogous manner to pigmentation. Eventually, distinctive surface sculpture replaced colouration (see Mapes \& Davis 1996, Westermann 1998). The findings of welldeveloped colour pattern in nautiloids having ribbed shells, as well as in strongly ornamented ammonoids (Mapes \& Larson 2016) and other molluscs, impeach this alternative hypothesis.

\section{Colour pattern as taxonomic character and its evolution}

The studied Silurian oncocerids of the family Oonoceratidae carry exogastric, cyrtoconic and slowly to moderately expanding shell. Their colour patterns consist of irregular transverse and undulating bands to more angular zig-zag bands. Closely related species with a similar shell shape such as Richardsonoceras forbesi, R. fraternum and Oonoceras geinitzi display also very similar type of zig-zag bands; differences are in the bands course, width and the proportions between pigmented and un-pigmented areas on the shell surface. More irregular, narrow zig-zag bands are documented in Oonoceras sp. A, where the colouration is preserved only on a small shell area in an early growth stage. According to Westermann (1998), Richardsonoceras and Oonoceras were forward moving demersal swimmers with a hydrodynamically stable shell. Taking the biological position of the shell into account, the general course of colour bands changed during life from horizontal to inclined.

The shell of ?Oonoceras impatiens, ?O. aff. impatiens and both species of Chromatoceras is less curved and shorter in comparison to Richardsonoceras and Oonoceras geinitzi, and their shell expansion is somewhat higher. Westermann (1998) speculated that such a shell form was more manoeuvrable and turbulence resistant compared to typical cyrtocones and suggests that the above nautiloids were demersal bottom feeders. The colour pattern in these cephalopods is more complex than in Richardsonoceras and certain Oonoceras; zig-zags are more or less disrupted by narrow, bilaterally symmetrical longitudinal zones with patches of pigment.

Irregular oblique colour bands in C. constringens are locally interrupted and fragmented. The bands are associated with longitudinally arranged rows of small coloured patches and the shell colouration is similar to that in ?O. cf. impatiens. Chromatoceras veteranum, closely related to C. constringens, exhibits the most complex colour pattern yet documented in nautiloids. Despite high variations, the pattern displays a combination of zig-zag bands and undulating transverse bands. Both may be disrupted into short segments and arranged into longitudinal zones.

Zig-zag bands sometimes tend to merge into large patches. However, the zig-zag pattern is more or less indicated. The variation of colour pattern in $C$. veteranum is much higher than that of other morphological characters of the species, namely shell shape and sculpture. This is the first documentation of high intraspecific variability in the colour pattern in Multiceratia. Colour patterning in $C$. veteranum possesses some common characters in patterning with ?Oonoceras impatiens. However, in the latter species, the pattern is less complicated. The discontinuous colour pattern was derived from zig-zag bands known in Oonoceras and Richardsonoceras

Concerning the colour pattern in ?Euryrizoceras decurio, Barrande (1866) published an idealised reconstruction of this pattern showing V-shaped zig-zags bands of constant width. The distribution of the dark grey pigment concentrated in two almost rectangular patches on the opposite side is confusing and may be influenced by diagenesis. However, relicts of the colour pattern on dorsum and venter indicate original colouring surrounding the whole shell. Barrande's idealised illustration was adopted by Ruedemann (1921) in his attempt to use colouration as tool to reconstruct the biologic shell orientation of Silurian brevicones (refigured by Berry 1928 and Teichert 1964); this has later been widely accepted (e.g. Stridsberg 1985, Westermann 1998).

In shell shape, Oocerina resembles some oncocerids of the family Oonoceratidae and represents a case of 

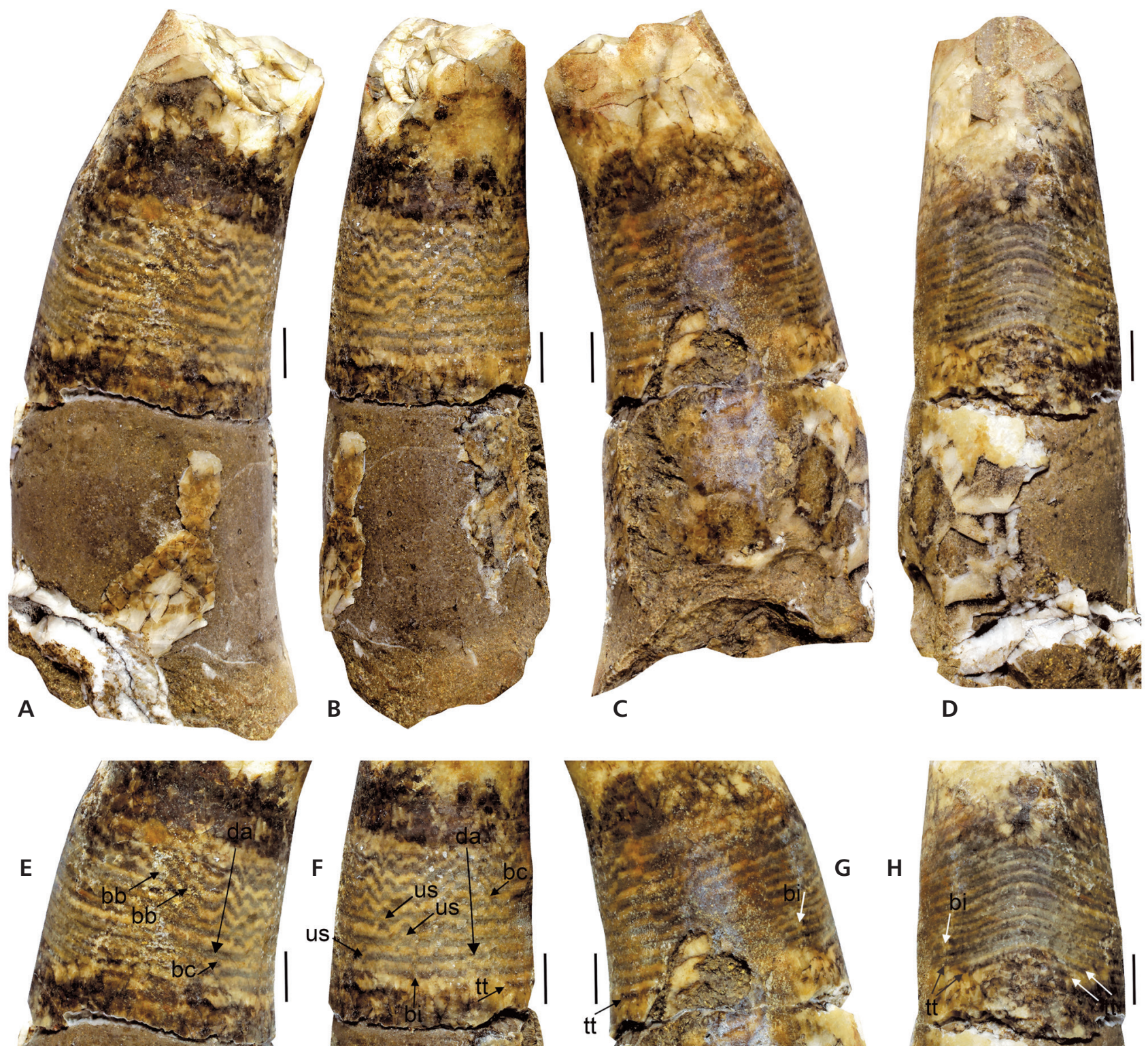

Figure 17. ?Oocerina cf. lentigrada (Barrande, 1866); NM-L 59875; upper Př́́dolí Series, transgrediens Zone; Karlštejn, Budňany Rock; Požáry Formation; lateral (A, C), dorsal (B), and ventral (D) views, for details se E-H below. Notice changes in course of transversal bands during ontogeny laterally and dorsally. For abbreviations see Fig. 10.

adaptive convergence. Oocerina differs from Oonoceras in having a more vaulted venter and a wider siphuncle with intrasiphonal deposits. Although the shell shape of Oocerina aff. lentigrada resembles Oonoceras, the colour patterns are quite different in both taxa. The colour pattern in Oocerina consists of narrow, densely spaced subparallel bands. Generally, the bands are transversal, passing into more or less oblique, sometimes branching bands.

There are only a few cases in which it is possible to trace changes of colour pattern in any successive or closely related species. In some cases, species belonging to the same nautiloid genus share a similar colour pattern (e.g. Peismoceras, Turek \& Manda 2010 and Richardsonoceras discussed in this paper). By contrast, there is evidence indicating that quite different colour patterns occurred within a single genus Phragmoceras (see Turek \& Manda 2011). Sometimes, closely related taxa display a different colour pattern as documented herein for Chromatoceras and Oonoceras.

Tracing the evolution of colour pattern based on such an incomplete fossil record is a difficult task. Species of the family Oonoceratidae, Oonoceras geinitzi, ?O. impatiens, ?O. cf. impatiens, Chromatoceras veteranum, C. constringens and Euryrizocerina normata (Manda \& Turek 2009b), co-occur at a single locality that represents a narrow stratigraphic interval in the lowermost Prrídolí Series. This 

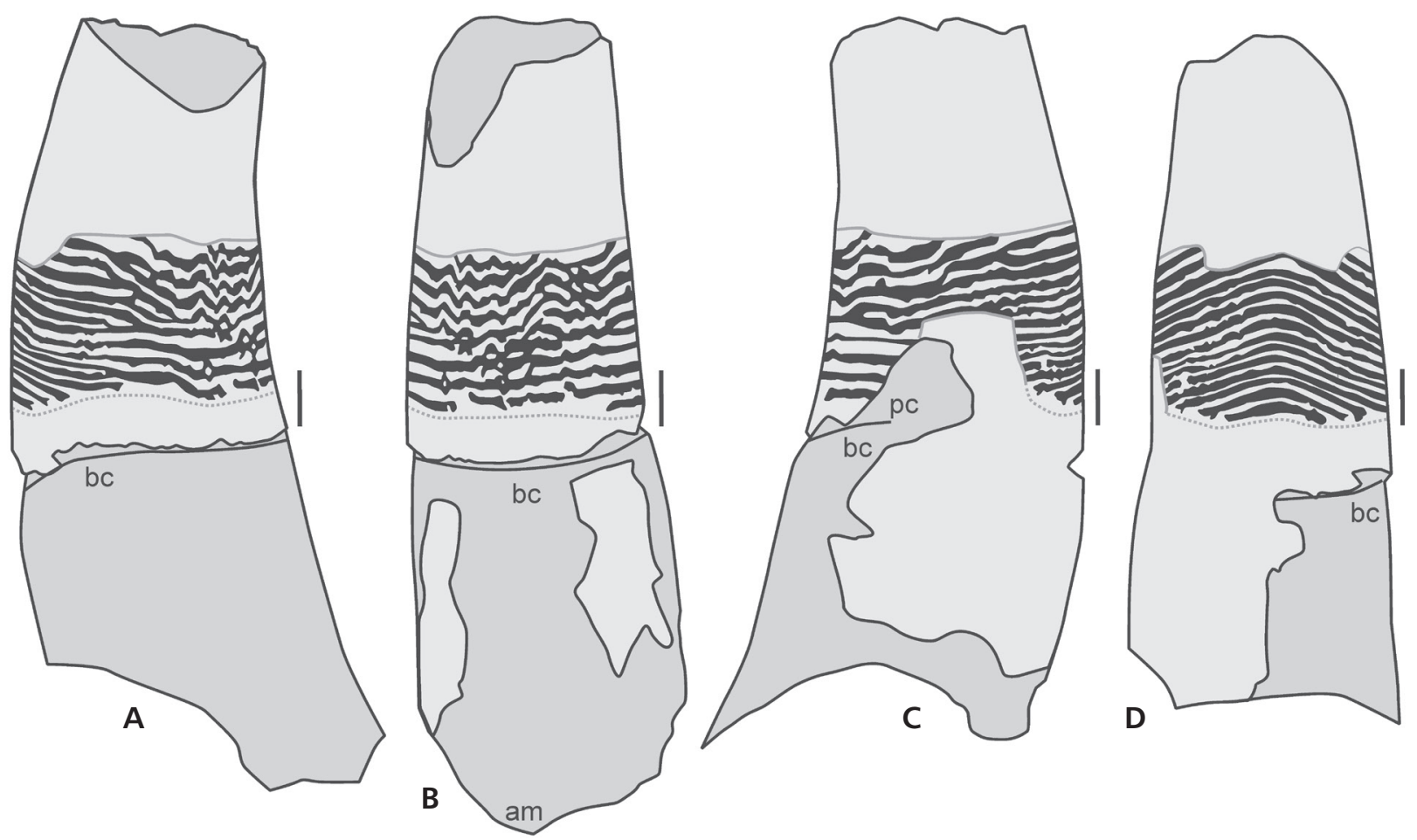

Figure 18. Schematic outlines of the colour pattern in ?Oocerina cf. lentigrada (Barrande, 1866). Specimen NM-L 59875 illustrated herein in the Fig. 17A-C, lateral (A, C), dorsal (B) and ventral (D) views. Abbreviations: bc - body chamber; pc - phragmocone. Scale bars equal $5 \mathrm{~mm}$.

indicates a high diversity of colour pattern in a cephalopod faunule and implies the possibility of pattern diversification in a monophyletic group. Zig-zag bands in moderately expanding cyrtocones evolved into an irregular complex pattern appearing in more derived, demersal forms characterised by a more rapidly expanding and much less curved shell. This supports the hypothesis that the pattern was in these cases exposed to a low selective pressure. Similar shell shape in closely related taxa does not necessarily mean that the taxa shared a similar type of colour pattern. Development of quite similar colour patterns in only very distantly related nautiloids (Tab. 1) suggests that this feature appeared repeatedly in evolution just like other morphological features.

\section{Asymmetry of colour patterns}

The stratigraphically oldest known nautiloid (Multiceratia) colour pattern in the Middle Ordovician oncocerid Hedstroemoceras Foerste, 1930a consists of simple symmetrical chevron bands; regular zig-zag bands appeared in the Late Ordovician with ?Rizoceras (Tab. 1). Other types of colour patterns are known from the middle and late Silurian (Tab. 2). High disparity and distinct asymmetry of colour patterns in some late Silurian species is documented here. The colour pattern in discosorids resembles the pattern in other oncocerids and it is known since the middle Silurian. Spiral colour bands and typical zig-zag pattern are known in tarphycerids (Tab. 1). All Ordovician and Silurian straight shelled orthocerids and pseudorthocerids that supposedly lived in the water column (passively floating or actively swimming (Peterman et al. 2019) display a rather regular symmetrical colour pattern consisting of longitudinal bands (Ruedemann 1921, Foerste 1930a, Frey 1989, Kröger et al. 2009, Manda \& Turek 2015, Kröger \& Aubrechtová 2019). Longitudinal bands have also been documented from shells of Ordovician and Silurian actinocerids (Foerste 1930a, Kobluk \& Hall 1976). In straight-shelled Ordovician demersal endocerids, only irregular and asymmetrical colour bands are known (Balashov 1964, Kröger 2011).

It is a question which type of colour pattern - symmetrical or asymmetrical - is evolutionarily older in cephalopods. Data concerning colour patterns in Late Cambrian cephalopods is still missing and the Ordovician record is still very scarce. The distinct asymmetry of the colour pattern and disruption of colour bands into separate segments or patches that evolved from irregular zig-zags are documented in this paper. The herein accumulated data support the hypothesis that irregular and asymmetrical patterns appeared more frequently in demersal cephalopods while the regular colour pattern was more common in more mobile cephalopods. 


\section{Ontogeny of colour patterns}

The characteristic colour pattern in Nautilus generally appears slightly before or immediately after hatching (Arnold et al. 2010, Swan \& Saunders 2010). The ventral and ventrolateral parts of the body chamber in mature recent nautilids are white because all these nautilids stop the secretion of the red-brown pigment (Collins \& Ward 2010). In Palaeozoic nautiloid cephalopods, the colour pattern was probably usually present over the entire surface of the shell in all growth stages. Similarly to the extant Nautilus, the original luminosity of the colour pattern probably changed during the growth of an individual (Stenzel 1964). However, the luminosity of colouring was strongly altered by taphonomy (Mapes \& Davis 1996, Mapes et al. 2010) and hardly can be objectively judged in the fossil record.

Data concerning colouration of fossil embryonic and juvenile shells are, however, sporadic (Ruedemann 1921, Foerste 1930a, Teichert 1964). Incompleteness of specimens and fragmentary preservation of colour patterns limited tracing of colour pattern changes through ontogeny in Palaeozoic nautiloids. Some of these nautiloids changed their mode of life during their post-embryonic development, which may be reflected in changes of colour patterns. A change in colour pattern during ontogeny was reported in the Silurian oncocerid "Cyrtoceras" parvulum Barrande, 1865 (Barrande 1865, 1870), in which straight transverse bands close to the apex follow regular zig-zag bands with increasing amplitude. In the early Carboniferous nautiloid Arcuatoceras Niko et al., 2009, different colour patterns are developed in juvenile and subadult shells. Niko et al. (2009) suggested that these colour patterns are homeomorphic to those of some Silurian oncocerids. If there is a similarity between changing habits and colour patterns between juvenile and sub-adult stages, then this is an argument for an adaptive value. In turn, this raises the question whether this was present in the last common ancestors of these groups or whether this evolved convergently (homoplastic).

The adapical part of the shell of Richardsonoceras forbesi is coloured with irregularly pigmented patches arranged roughly obliquely to the shell axis (Fig. 2C). Later in ontogeny, obliquely transverse zig-zag bands appeared. The thinning of the three most adoral colour bands is documented in a specimen of $R$. forbesi (Figs 1F, G; 2E); the body chamber was thus somewhat lighter in colour than the phragmocone. Decreased width of the two most adoral colour bands is also developed ventrolaterally in another specimen of $R$. forbesi (Figs 1B, 2D). A weak apertural constriction and a thickening of the apertural edge indicate maturity of these two specimens. Cowen et al. (1973) interpreted the decreasing width of colour bands as counter-shading like in modern nautilids. Irregular colour patterns in the apical part of the phragmocone of Eurizocerina normata (Manda \& Turek 2009b) probably changed during growth into zig-zag bands like in Richardsonoceras, as well.

The preserved shell part of ?Oocerina cf. lentigrada displays an increasing regularity in colour patterns through ontogeny. Wavy and sometimes also branching transverse bands pass laterally and dorsally into almost straight bands. Regularly arranged transverse bands on the venter, subparallel to the growth lines, did not change their course. Close to the base of the body chamber, colour bands disappear laterally and bands end with a weak thickening. Fragments of the shell wall on the internal mould of the body chamber indicate that there is the possibility that the body chamber was not pigmented ventrally like in recent Nautilus. Except for Cretaceous and recent nautilids, the lack of colour patterns in mature shells is unknown in fossil nautiloids (Mapes \& Evans 1995).

The juvenile shell of $C$. veteranum displays irregularly arranged patches of pigment, later passing into disrupted irregular bands; the amplitude of V-shaped bands decreases during shell growth. Finally, in mature shells, irregular transverse bands sometimes surround un-pigmented patches close to the base of the body chamber. Data presented here imply that colour patterns changed throughout ontogeny already in some Silurian nautiloids, often giving the adult body chamber a brighter colour. This suggests a Silurian origin of counter-shading, which makes sense in the light of the Silurian radiation of jawed fish (e.g. Klug et al. 2010, Brazeau \& Friedman 2015).

\section{Function of colour patterns}

The presumption that the colour pattern in Nautilus served as camouflage is an important actualistic model for the ecological role of colouration in Palaeozoic nautiloids. Miller (1947) and Stenzel $(1957,1964)$ suggested a protective function of colouration. Later, Cowen et al. (1973) reinterpreted these suggestions in terms defined by Cott (1940) and considered the Nautilus colour pattern as an example of disruptive camouflage and counter-shading (see also Packard 1988, who pointed out similarities with colouration in fish). In the most recent synthesis of Nautilus biology (Sounders \& Landman 1987, 2010) there is, however, just one remark concerning "protective colouration" in juveniles (Arnold et al. 2010, p. 390). Ward (1987, p. 196) referred to Cowen et al. (1973) and suggested that Nautilus populations from New Caledonia and New Hebrides differ in colouration. Because in both areas, Nautilus animals "are commonly seen in depth much shallower than Nautilus from other areas with warmer surface water...it may be that shallower water habit makes more coloration an adaptive trait" (Ward 1987, p. 196). Mapes \& Larson (2016, p. 41) emphasized that modern nautilids "might have lived below the euphotic zone where visibility is extremely 


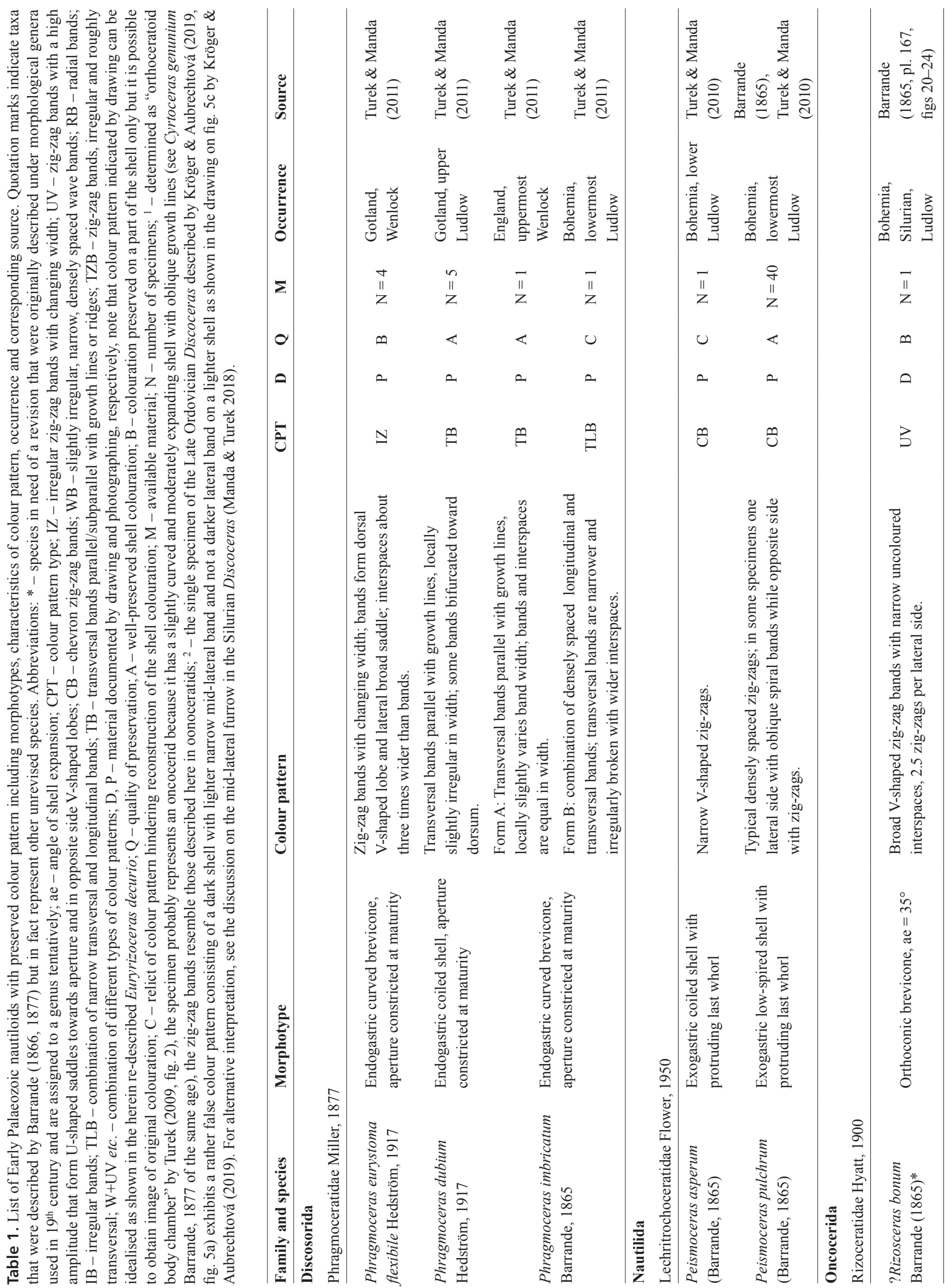




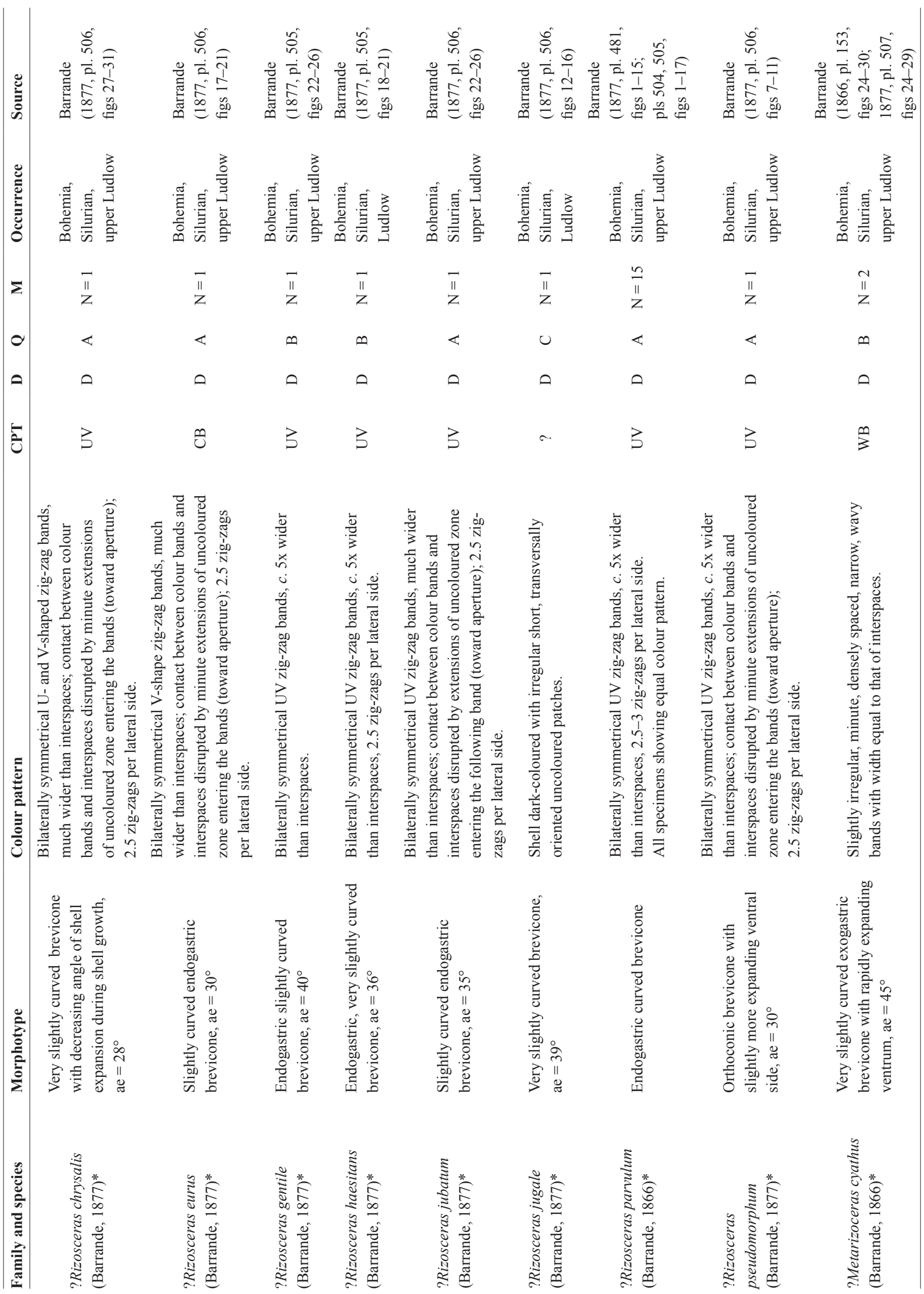




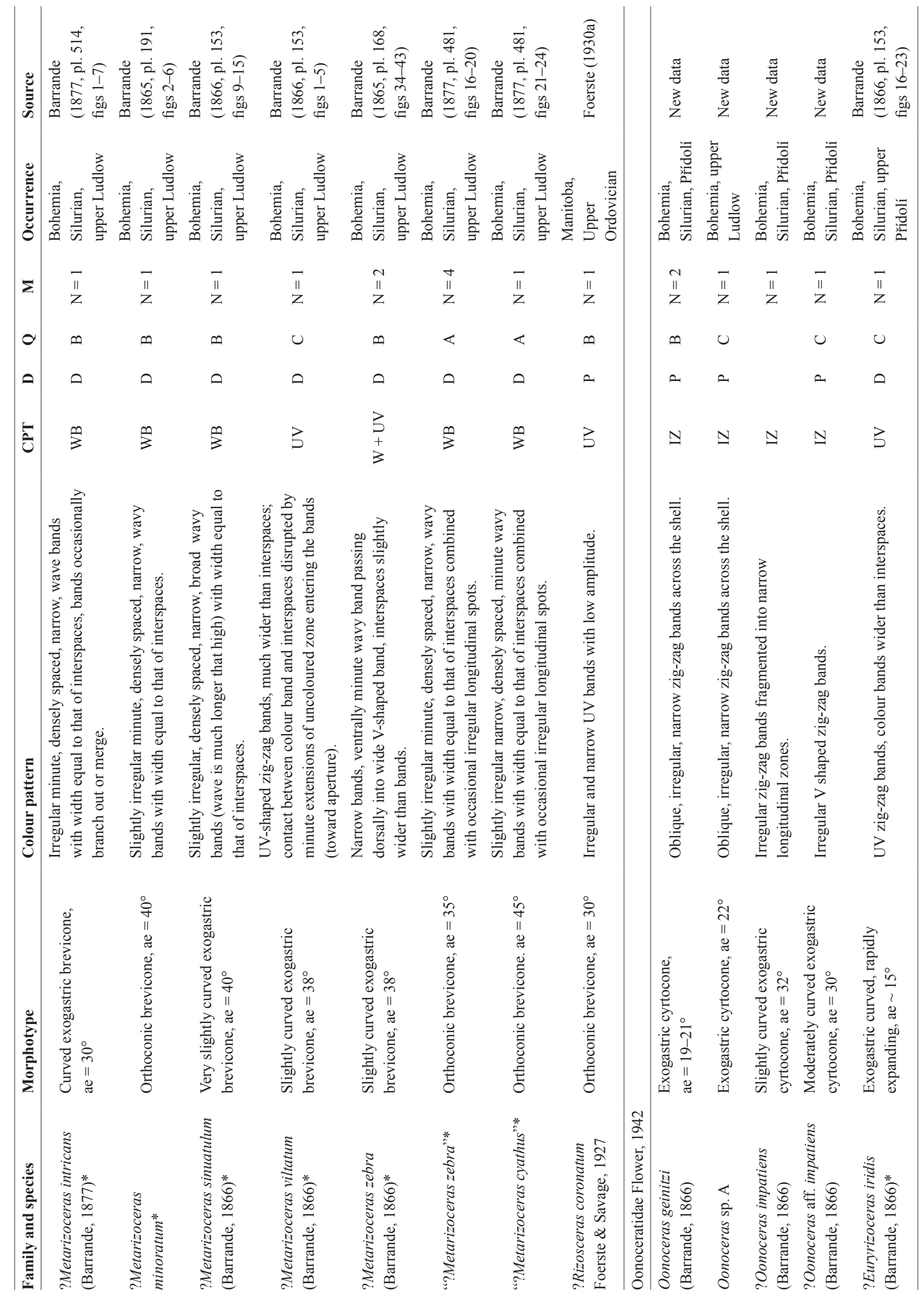




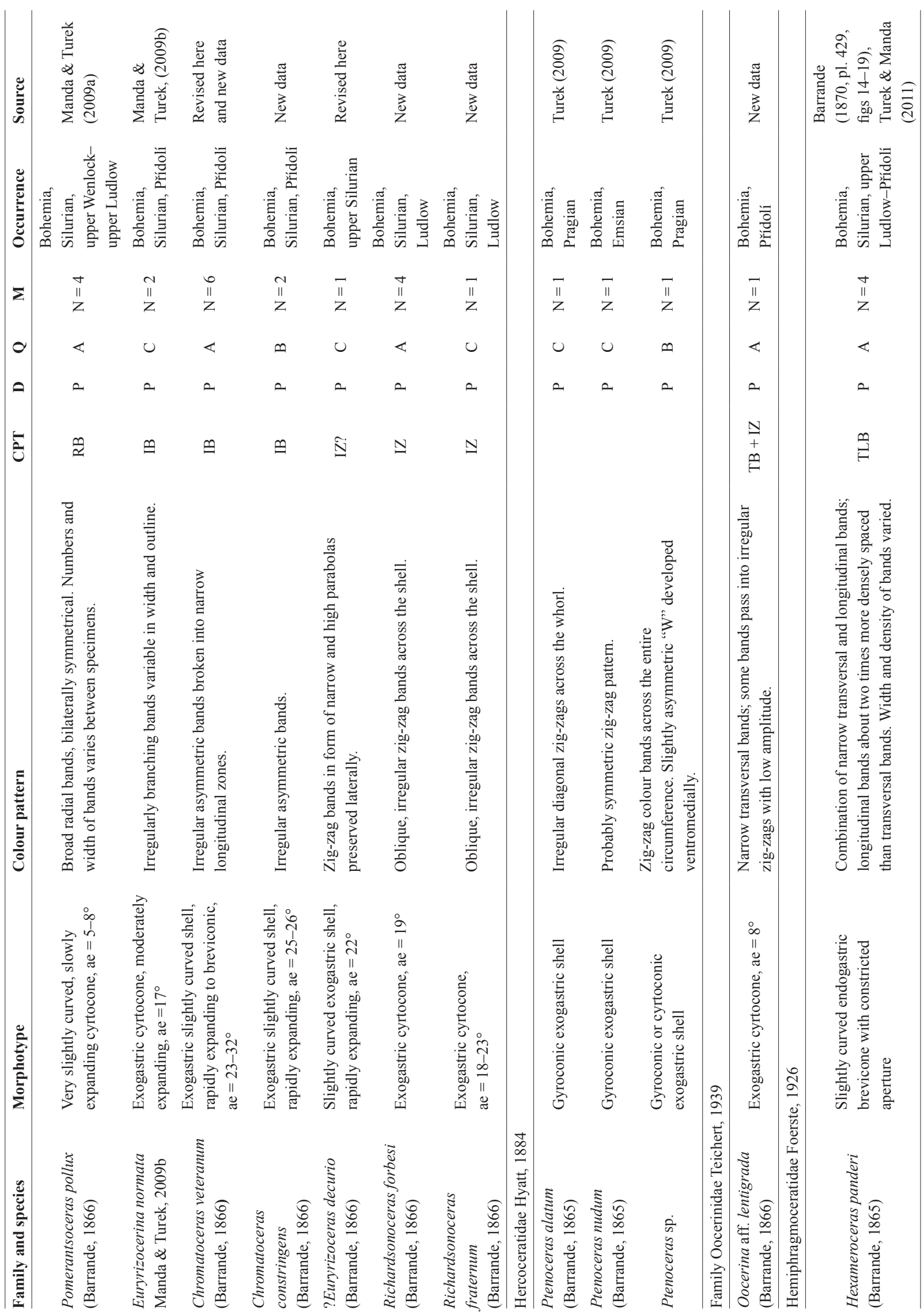




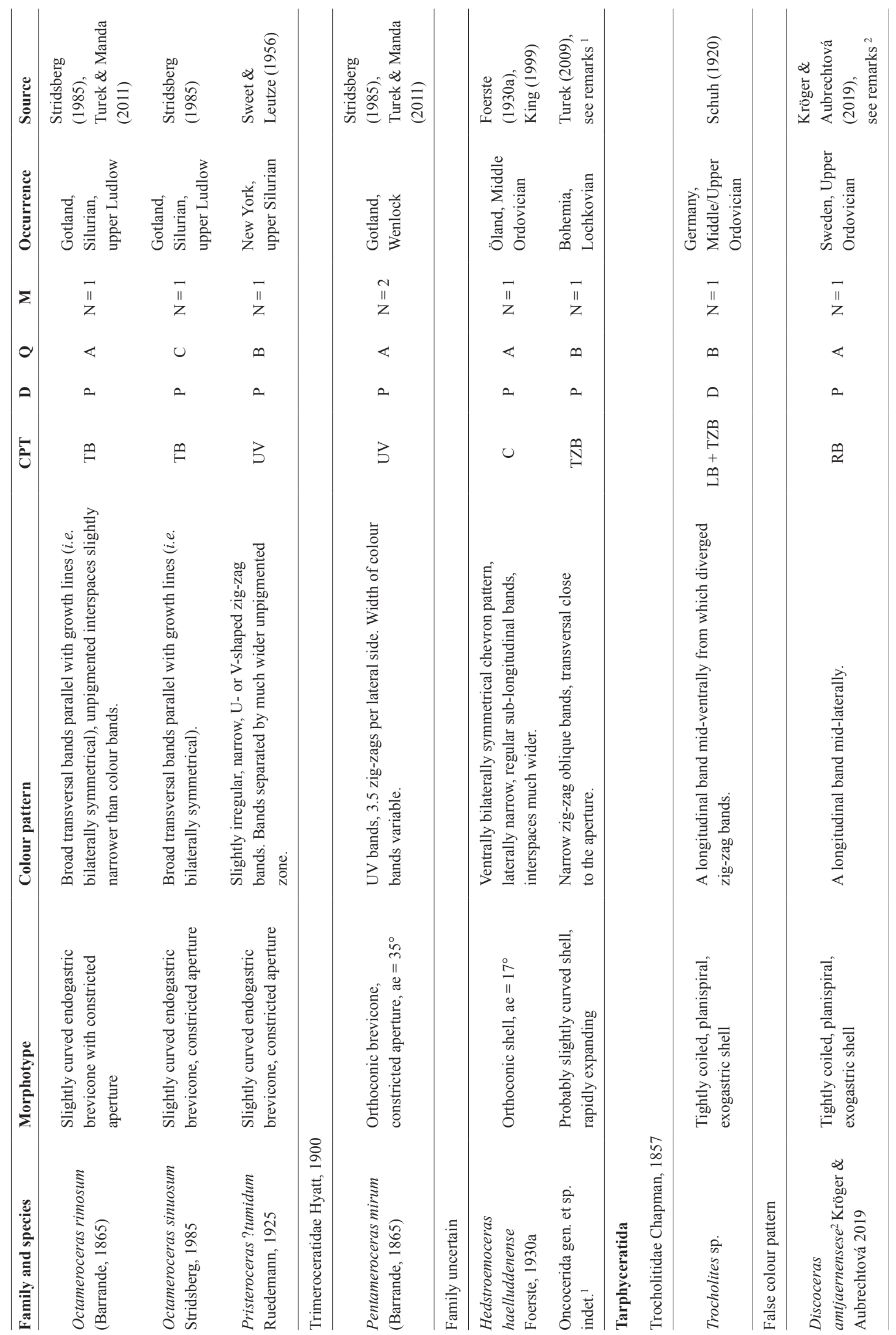


limited or totally lacking and detection by other visual animals may be extremely limited". Only at night, nautilids move into shallower water. However, the daylight is not the only source of light to which nautilids are exposed. Bioluminescence may be similarly important (Muntz 1987, Johnsen 2005). Also, there is still limited data concerning the ecology of Nautilus juveniles (Saunders \& Ward 1987, Arnold et al. 2010). According to the opinion of Ward et al. (2016), the stratigraphic range of Nautilus is much longer than previously thought (Ward 1987, Teichert \& Matsumoto 1987, Saunders et al. 1996). Ward et al. (2016) argued that some ancient nautilid genera are congeneric with Nautilus, which thus originated possibly in the Middle Jurassic or the Early Cretaceous with maximum diversity during the Late Cretaceous. Occurrences in Mesozoic shallow water facies indicate that Nautilus inhabited the euphotic zone at that time. Shell colouring may thus be an evolutionary relict with no or little selective value like in some other molluscs (see Williams 2017).

All nautiloids lived in the water column and thus shell colouration was visible if the shell surface was not covered by epizoans (which is likely) and if the animal inhabited the photic zone (which applied likely to many Palaeozoic taxa). The function of colouration should be related to cooccurrences with animals with vision. The shell surface of coloured nautiloids from the Prague Basin is well preserved with no traces of epibionts or attachment traces of epifauna that would hide the colouration. Similarly, in recent nautilids, syn vivo encrusters are also very rare (Seilacher \& Gisshlick 2015). Cephalopod limestone biofacies in the Prague Basin correspond with 2 and upper 3 life position of Boucot's benthic communities (Havlíček \& Štorch 1990, 1999). Brett et al. (1993) summarised absolute depth indicators in the Silurian benthic communities, which make possible their depth estimation. The boundary between 4 and life position corresponds with the lower limit of the euphotic zone (Brett et al. 1993). Cephalopods with coloured shells accordingly inhabited the euphotic zone in the Prague Basin. Nautiloids with preserved colour patterns occur in faunas including both prey and predators with welldeveloped vision. This is consistent with widely accepted concept that most brevicones have lived in moderate depths anyway (e.g. Westermann 1998).
There was likely a strong selective pressure on shell colour and colour patterns serving as camouflage or warning or for sexual display since the Cambrian explosion and the development of the first image-forming eyes, because during the Cambrian explosion, predators evolved better visual acuity and colour vision (Kobluk \& Mapes 1989, Aberhan et al. 2012). Despite some doubts concerning the function of colouring in recent nautilids, it is reasonable to assume that colour patterns in early Palaeozoic nautiloids served as light screening or camouflage (Stridsberg 1985, Kobluk \& Mapes 1989, Westermann 1998). Speciesspecific colour patterns and their changes through ontogeny in oncocerids with a slightly or moderately curved shell are consistent with a protective function of shell colouration.

\section{Conclusion}

1) Among Palaeozoic nautiloids, shell colour patterns are best documented in the order Oncocerida. The pattern is already known in 47 species and they show all types of colour patterns known in nautiloids. The vast majority of oncocerids with preserved colour patterns possess straight or very slightly curved breviconic shells; only very scarce cases of oncocerids with a moderately expanding and curved or coiled shell have been published that show colour patterns. The colour patterns described herein have been discovered in seven Silurian oncocerid species of the families Oonoceratidae and Oocerinidae with cyrtoconic shell.

2) Zig-zag bands represent the characteristic type of colour patterns in oncocerids with cyrtoconic shell of the family Oonoceratidae. The general course of individual pigmented bands is roughly transversal. Differences in zig-zag patterns among individual taxa comprise the width of bands and the amplitude of triangles in the zig-zag bands; bands may split into more or less isolated segments or irregularly bounded patches of dark pigment. Only in one specimen of the family Oocerinidae, the colour patterns form transversal wavelets. The zig-zag patterns, disruptions and other aspects of the colour patterns are characteristic for patterns self-organized by diffusion-reaction processes. Accordingly, the variation also roots in this self-organisation.

Figure 19. Chromatoceras veteranum (Barrande, 1866); A-C, J - specimen NM-L 14299 illustrated by Barrande (1866, pl. 208, fig. 22) as Cyrtoceras fallax Barrande, 1866, lowermost Př́́dolí Series, Kosoř locality, Kopanina Formation, lateral (A), dorsal (B), ventral (C) views and detail (J) of a healed injury in adapical region (hi); D - specimen NM-L 21751, illustrated by Barrande (1877, pl. 514, figs 13-17), lowermost Přídolí Series, Praha-Lochkov, Kopanina Formation, phragmocone ventrally polished, showing siphuncle; E, F, I, K -specimen NM-L 14298 (holotype by monotypy; Barrande 1866, pl. 208, fig. 22, refigured herein also in the Fig. 11I-P), lowermost Př́idolí Series, parultimus-ultimus Zone, Kosoř locality, Kopanina Formation; G, H - specimen NM-L 10127 (holotype by monotypy of Cyrtoceras sica Barrande, 1866, pl. 124, figs 6-11), lowermost Př́ídolí Series, Praha-Slivenec, Kopanina or Požáry Formation, G - a part of siphuncle polished ventrally, H - lateral view; L, M - specimen NM-L 46890 illustrated herein also in Figs $10 \mathrm{H}-\mathrm{J}, \mathrm{M}-\mathrm{O}$ and $13 \mathrm{~A}-\mathrm{C}$, lowermost Př́́dolí Series, parultimus-ultimus Zone; Praha-Lochkov, U topolů section, Kopanina Formation, lateral (L) and dorsal (M) views. Except siphuncle details (D, G), all specimens were whitened with ammonium chloride before photographing. Abbreviations: hi - healed injury; pf - polished part of phragmocone. Scale bars equal $5 \mathrm{~mm}$. 


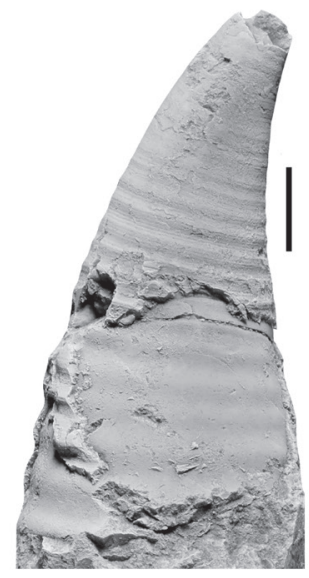

A

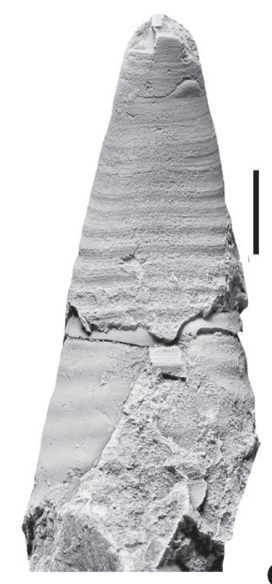

B
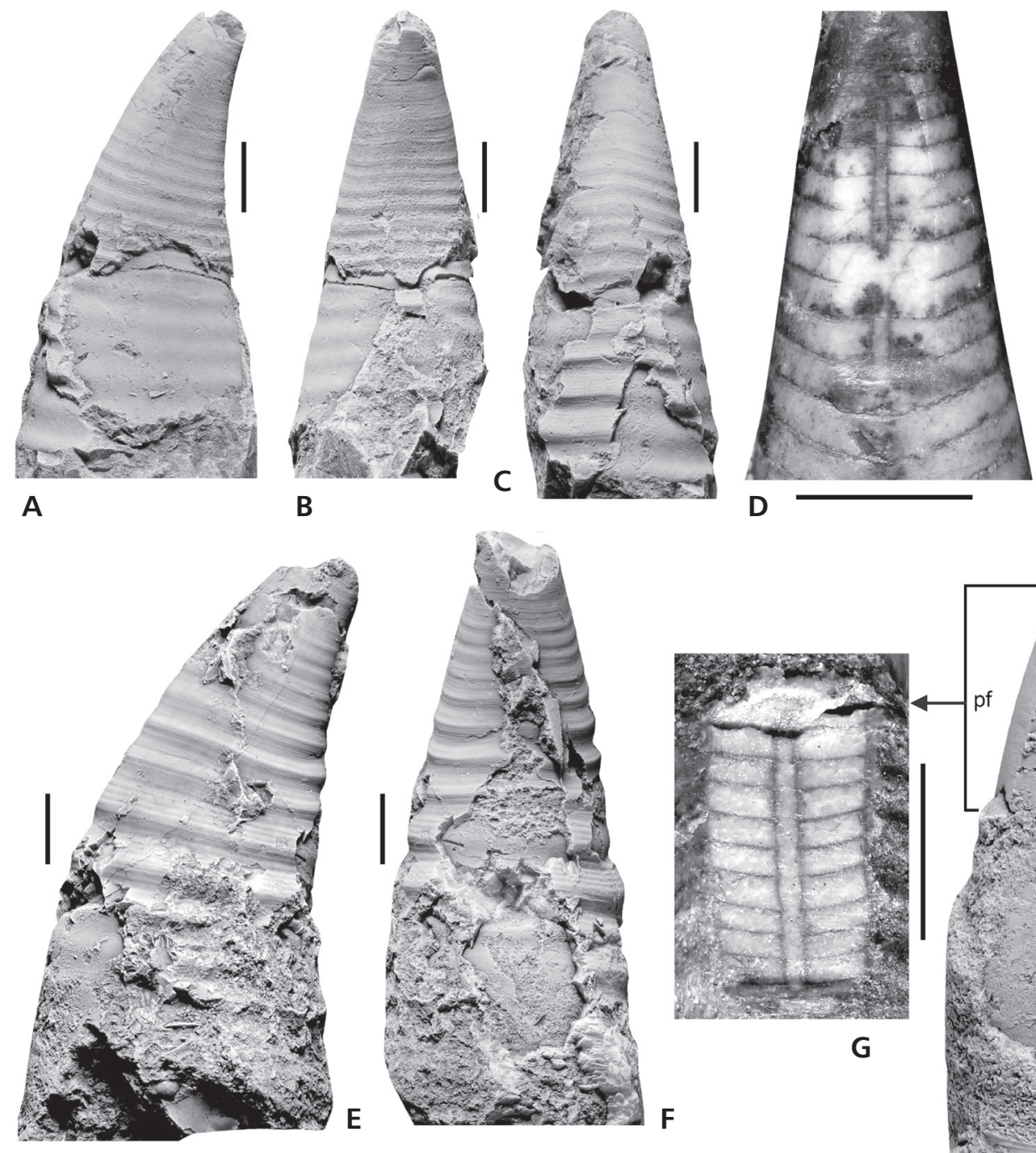

.
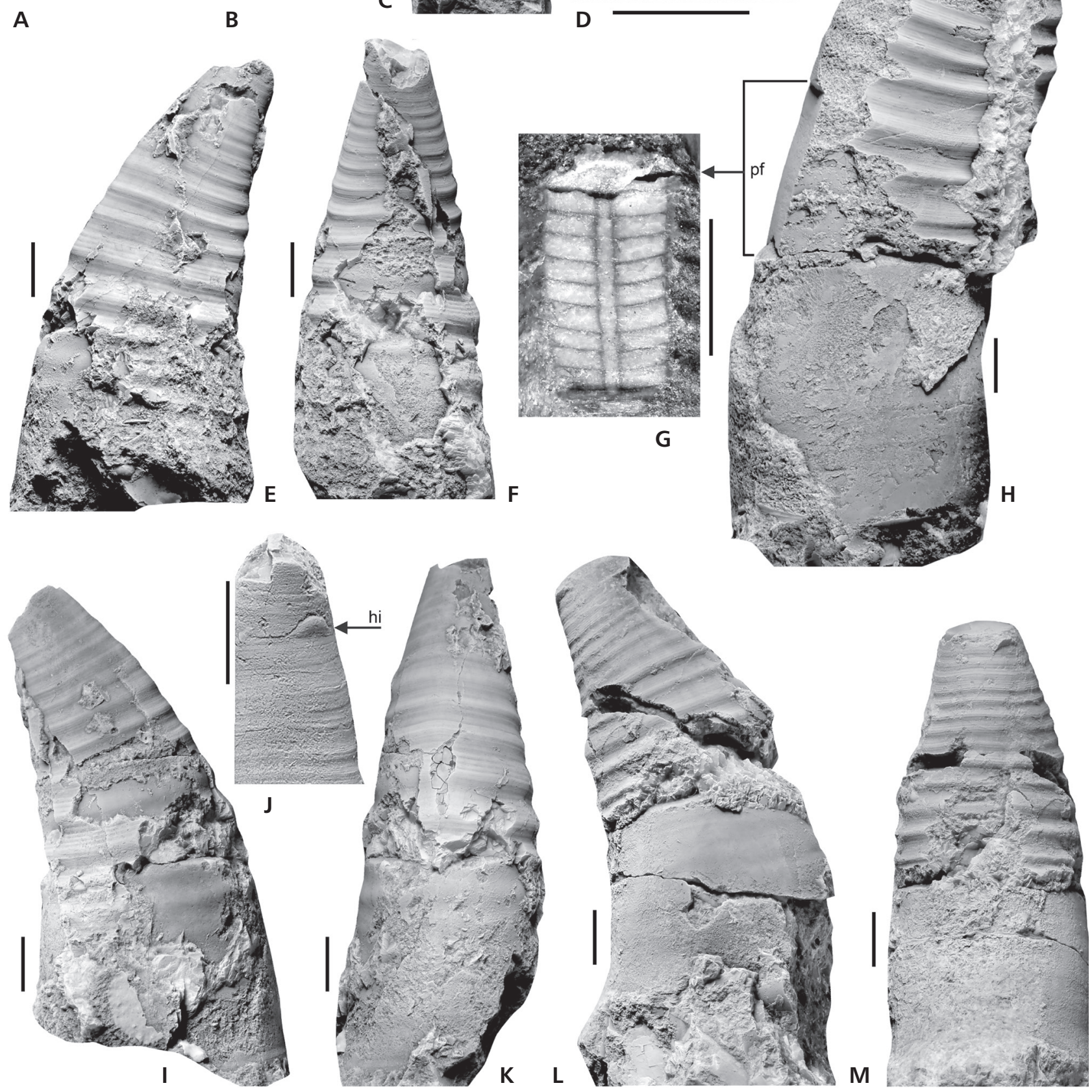
3) New data confirm that the colour patterns in oncocerids originally surrounded the entire shell from early juvenile growth stages to maturity. The ratio between pigmented and unpigmented surfaces is usually close to 1 . In the case of ?Oocerina cf. lentigrada, the venter of the mature shells was rather poorly pigmented without colour patterns.

4) Striking asymmetry of colour patterns in oncocerids has been found especially in the species of Chromatoceras gen. nov. Another case of colour pattern asymmetry was documented only in some specimens of the Silurian tarphycerid Peismoceras pulchrum, which possesses a lowspired torticone shell (Turek \& Manda 2010). Despite the high variation of the colour patterns in some taxa, the general character of the pattern is more or less specific for individual genera or species and thus can be used for taxonomy with some reservation. This variation roots in the self-organisation to a great degree.

5) Changes in colour patterns during ontogeny in some oncocerid species is here documented. Frequently, irregular colour patterns in juveniles changed to more regular patterns in the subadult stage (e.g. Richardsonoceras). The decreasing amplitude of zig-zag colour bands throughout post-juvenile growth and the decreasing width of colour bands in the mature shell are documented here. Occasionally, the colour patterns became more irregular again in the subadult stage (Chromatoceras veteranum).

6) Dark colour bands in the form of two quite different types of pattern occur in some specimens of Chromatoceras veteranum: between isolated segments of zig-zag bands, short and narrow slightly undulated transverse bands are inserted. Due to the suppression of zig-zag bands, a new pattern characterised by transverse bands appeared. The asymmetrical pattern exhibits a high intraspecific variation unknown from other nautiloids

7) The Silurian oncocerids discussed herein inhabited the euphotic zone and it is likely that their colouring served for camouflage. High intraspecific variation of colour patterns in some species and differentiation of colour patterns in closely related taxa possessing similar shell form indicate a weak selective pressure on the evolution of the colour patterns. Asymmetric colour patterns are documented in probably more demersal forms.

\section{Systematic appendix}

Subclass Nautiloidea Agassiz, 1847

Order Oncocerida Flower in Flower \& Kummel (1950)

Family Oonoceratidae Flower, 1942

\section{Genus Chromatoceras gen. nov.}

Type species. - Cyrtoceras veteranum Barrande, 1866; lowermost Př́idolí Series of Bohemia.

Etymology. - Name derived from the Greek word of chromos meaning colour.

Diagnosis. - Oonocerid with rapidly expanding exogastric shell with a slightly curved venter throughout ontogeny while the dorsum is curved only in early growth stages; later in ontogeny, the shell is almost straight; shell with prominent more or less regularly spaced transverse ribs; hyponomic sinus very shallow and broad; colour patterns are complex and colour bands are fragmented into individual parts, segments of zig-zag bands, sometimes fusing into irregularly bounded patches alternating with segments of thinner undulating or adapically vaulted transverse bands.

Discussion. - The diversity of oncocerids possessing an exogastric, curved shell and a thin siphuncle is relatively high throughout latest Ludlow and early Př́idolí strata of Central Bohemia (Krríž et al. 1986, Turek 1992, Krríž 1998). Their phylogenetic relationship is, however, generally poorly studied. Besides widely distributed taxa, there are also some endemic forms with very short stratigraphic range known from this area (Manda \& Turek 2009b). Chromatoceras, represented by two species, is another example of an oncocerid genus with a very limited geographic distribution, known only from Prague Basin, and a short stratigraphic range. The species of Chromatoceras resemble the stratigraphically older ?Oonoceras imperiale (Barrande, 1866). The exogastric shell in the latter species is curved, moderately expanding, with well-developed ribs and a moderately compressed cross section. With two species of Chromatoceras, it shares the following features: decreasing shell expansion and curvature during later shell growth stages and pronounced growth lines arranged into regular elevated zones. Both species of Chromatoceras differ from ?Oonoceras imperiale in having a short and less compressed shell with a dorsum that is only very slightly curved, a vaulted venter and in ribs appearing very early in ontogeny.

Species included. - Chromatoceras veteranum (Barrande, 1866) and C. constringens (Barrande, 1866).

Chromatoceras veteranum (Barrande, 1866)

Figures 10-13, 19

1866 Cyrtoceras veteranum Barr.; Barrande, pl. 208, fig. 21.

1866 Cyrtoceras sica Barr.; Barrande, pl. 124, figs 6-11. 
partim 1886 Cyrtoceras fallax Barr.; Barrande, pl. 208, fig. 22.

1867 Cyrtoceras veteranum Barr.; Barrande; p. 571.

1867 Cyrtoceras sica Barr.; Barrande, pp. 529, 530.

1877 Cyrtoceras veteranum Barr.; Barrande, pl. 514, figs 13-17.

1921 Cyrtoceras veteranum. - Ruedemann, p. 80.

1930a Cyrtoceras veteranum. - Foerste, p. 121.

Holotype. - By monotypy, specimen NM-L 14298 figured by Barrande (1866) in pl. 208 as fig. 21.

Type horizon and locality. - Silurian, lowermost Přídolí Series, parultimus-ultimus Biozone; Kozořz e $\mathrm{e}_{2}$ by original designation (= Kosoř Village, area of the Hvíždalka Natural Monument, and adjacent area to the south, to the NNE from Kosoř Village).

Material. - Holotype and seven additional specimens (their inventory numbers are listed in Tab. 2).

Description. - Moderately-sized oncocerid with sl = $67 \mathrm{~mm}$, max. reconstructed $\mathrm{sh}=27 \mathrm{~mm}$, and maximum reconstructed $\mathrm{sl}=77 \mathrm{~mm}$. Slightly curved exogastric shell, rapidly expanding, ae $=23-32^{\circ}$; in fully grown specimens, the angle of shell expansion decreases to about $12^{\circ}$ in the body chamber. Venter is much more curved than the slightly curved dorsum. Body chamber length is less than one third of total shell length. Cross section slightly compressed with vaulted venter but flattened dorsum $(\mathrm{sh} / \mathrm{sw}=1.1-1.3)$. Suture straight, obliquely oriented with respect to the longitudinal axis of the shell, septa slightly vaulted and densely spaced. Apical part of the shell is smooth. Densely spaced transverse ribs appear at shell height of $8 \mathrm{~mm}$. Hyponomic sinus is very shallow and broad, in fully-grown specimens almost not visible. Siphuncle narrow, tubular, situated close to ventral side.

Remarks. - In shell shape, cross section, sculpture and colour patterns, "Cyrtoceras" sica corresponds with other specimens of $C$. veteranum; we therefore regard both taxa as conspecific.

Occurrence. - Silurian, lowermost Přídolí Series, parultimus-ultimus Biozone; Kopanina Formation; PrahaLochkov, U topolů section (a bed of dark grey cephalopod packstone just above the base of the Prrídolí; Manda \& Turek 2009b, fig. 1) and Praha-Kosoř, Praha-Slivenec, a Barrande locality.

\section{Chromatoceras constringens (Barrande, 1866)}

Figure 14, 15, 20

1866 Cyrtoceras constringens Barr.; Barrande, pl. 156, figs $1-6$.

1867 Cyrtoceras constringens Barr.; Barrande, pp. 541, 542.

Holotype. - Holotype by monotypy, specimen NM-L 669 illustrated by Barrande (1866) in pl. 156, figs 1-6 (refigured here as Figs 14A-D, 20D-G).

Type horizon and locality. - Silurian, lowermost Přídolí

Table 2. Shell dimensions in Chromatoceras. Abbreviations: sl - maximum shell length; sh - maximum shell height; sw - max. shell width; bcl - body chamber length, $\mathrm{sh} / \mathrm{sw}$ ratio; $\mathrm{sh}_{\min }-$ minimum shell height; $\mathrm{sw}_{\max }-$ minimum shell width; sh2 - shell height at base of body chamber; ae - angle of shell expansion; * - indicates holotype. All measurements in millimetres.

\begin{tabular}{|c|c|c|c|c|c|c|c|c|c|}
\hline Taxa/inv. number & sl & sh & sw & bcl & $\mathbf{s h} / \mathbf{s w}$ & $\mathbf{s h}_{\text {min }}$ & $\mathbf{s w}_{\min }$ & $\operatorname{sh} 2$ & ae \\
\hline \multicolumn{10}{|l|}{ C. veteranum } \\
\hline NM-L 14298* & 43.6 & 19.7 & 17 & 16.1 & 1.16 & 6.1 & 6 & 18 & $23^{\circ}$ \\
\hline NM-L 10127 & 66.0 & c. 28 & c. 20.5 & 24.5 & 1.15 & 11.2 & 9.5 & 22.0 & - \\
\hline NM-L 14299 & 31.7 & 18.3 & 17.3 & 12.2 & 1.06 & 4 & 4 & 12.7 & $22^{\circ}$ \\
\hline NM-L 21751 & 35.2 & 15.1 & 14.1 & 13 & 1.07 & 4.9 & 4 & 12.5 & $21^{\circ}$ \\
\hline NM-L 46578 & 26.5 & 19.8 & 15.0 & 13.6 & 1.32 & 10.4 & 9.3 & 15.3 & $26^{\circ}$ \\
\hline NM-L 46580 & 48.1 & 22.4 & 18.1 & 15 & 1.24 & 11.4 & 11.5 & 19.3 & $24^{\circ}$ \\
\hline NM-L 46581 & 12.6 & - & - & - & - & 3.8 & - & - & - \\
\hline NM-L 46890 & 44.0 & c. 23 & 19.5 & 17.9 & 1.18 & 7.9 & 7.9 & 20.0 & $32^{\circ}$ \\
\hline \multicolumn{10}{|l|}{ C. constringens } \\
\hline NM-L 669* & 38.0 & 24.5 & 21.0 & 20.2 & 1.17 & 12.9 & 12.2 & 21.5 & $25^{\circ}$ \\
\hline NM-L 46579 & 42.0 & 25.2 & - & 18.3 & - & 13.8 & 12.6 & 23.9 & $26^{\circ}$ \\
\hline
\end{tabular}



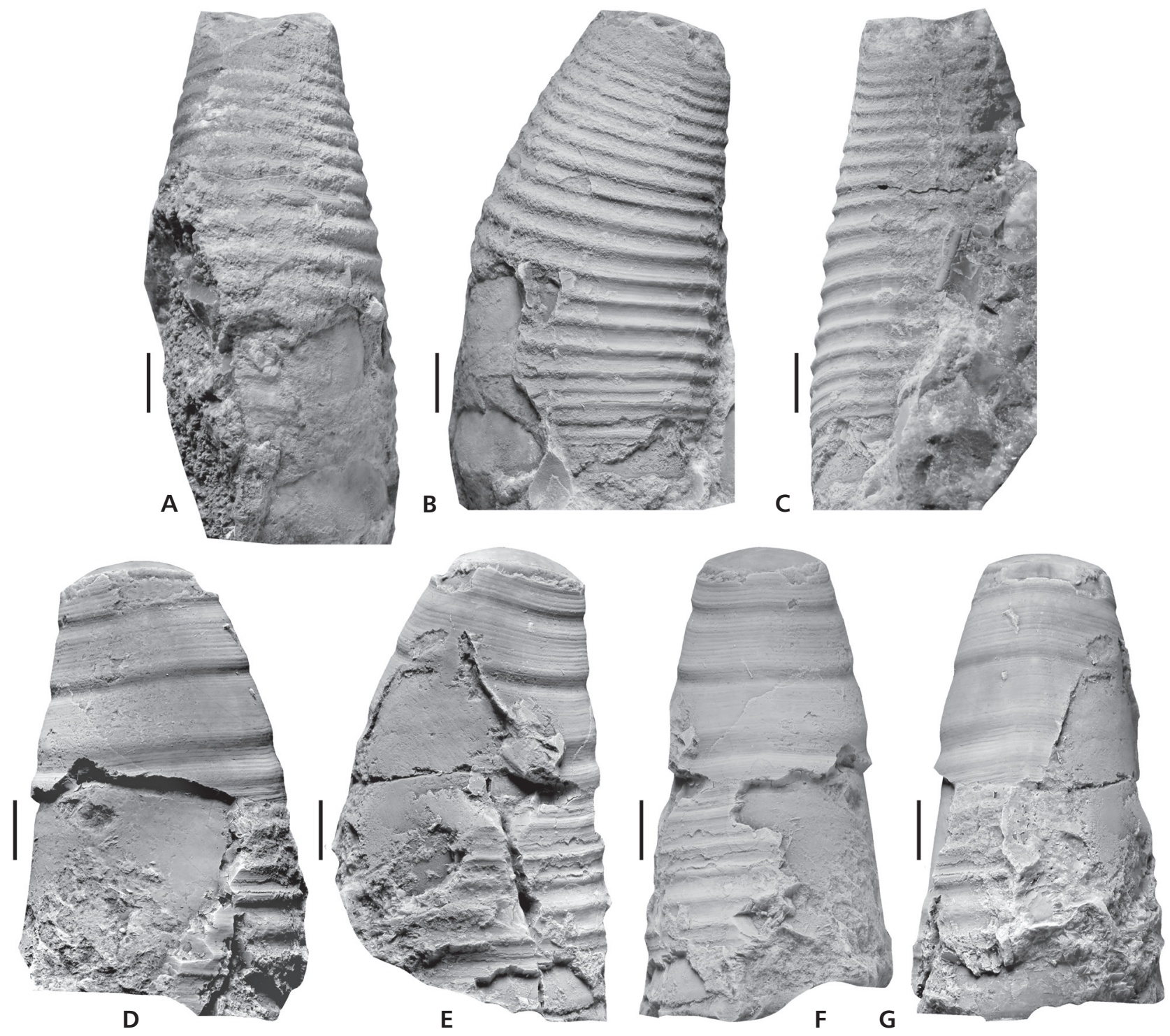

Figure 20. Chromatoceras. constringens (Barrande, 1866); A-C - specimen NM-L 46579 illustrated herein also in the Fig. 14E, F, lowermost Př́idolí Series, parultimus-ultimus Zone, Praha-Lochkov, U topolů section, Kopanina Formation, ventral (A) lateral (B), and dorsal (C) views; D-G - specimen NM-L 669 illustrated herein also in Fig. 14A-D, lowermost Př́idolí Series, Kosoř locality, Kopanina Formation, sinistral (D), dextral (E), dorsal (F) and ventral $(\mathrm{G})$ views. Notice anomalous character of shell sculpture. All specimens were whitened with ammonium chloride before photographing. Scale bars equal $5 \mathrm{~mm}$.

Series, parultimus-ultimus Biozone; Kozořz e $e_{2}$ by original designation (= Kosoř Village, area of the Hvíždalka Natural Monument, and adjacent area to the south, to the NNE from Kosoř Village).

Material. - In addition to the holotype only one specimen: NM-L 46579.

Description. - The slightly curved, exogastric shell of Chromatocera constringens is small with a $\mathrm{sl}=42 \mathrm{~mm}$, $\mathrm{sh}=25 \mathrm{~mm}$, and length of the complete reconstructed shell roughly $65 \mathrm{~mm}$. Shell is rapidly expanding, ae $=25-26^{\circ}$.
Body chamber occupies approximately one third of the shell length. Shell is slightly compressed, broadly elliptic in cross section $(\mathrm{sh} / \mathrm{sw}=1.14)$. Sutures obliquely oriented with respect to the longitudinal shell axis with shallow lateral lobe; septa moderately vaulted and densely spaced. Shell sculpture on phragmocone consists of fine transversal growth lines forming low and narrow elevations, which are not evident on the internal mould. Growth walls straight, transversal, slightly asymmetric in cross section (adapical part of ribs wider than adoral part). Hyponomic sinus is very shallow and broad. Narrow siphuncle with slightly expanded segments is situated close to venter. 
Remarks. - Shell shape and size, thin siphuncle and densely spaced septa, body chamber length and cross section in C. constringens correspond to the same features in C. veteranum. C. constringens differs from the latter species in having lower and more densely spaced ribs.

The shell sculpture of the holotype of $C$. constringens is peculiar; the preserved adapertural part of the phragmocone displays two wide segments separated by deep transversal furrows. Their surface is flat, bearing only growth lines. Densely spaced growth lines are typical for Chromatoceras and are developed on the body chamber. This sculpture is interpreted as a growth anomaly with respect to the normal appearance of sculpture on the holotype body chamber and the character of shell sculpture in one other specimen assigned to this species. The distinct difference in the colour pattern between $C$. constringens and C. veteranum confirms Barrande's concept of two separate species.

Occurrence. - Silurian, lowermost Př́ídolí Series, parultimus-ultimus Biozone; Praha-Lochkov, U topolů section and Praha-Kosoř, a Barrande's locality.

\section{Acknowledgments}

The research was financially supported by the Ministry of Culture of the Czech Republic (DKRVO 2020/2.IV.a, National Museum, 00023272 - VT) and the Strategic Research Plan of the Czech Geological Survey and the Czech Grant Agency 205/09/0703 (ŠM). The authors thank L. Zedník (Prague) for providing one of the studied specimens, M. Aubrechtová (Prague) for the careful reading and suggestions to the manuscript and reviewer C. Klug (University of Zurych) for his valuable comments and improving English. The authors thank L. Váchová (National Museum, Prague) for photographing of all of the specimens.

\section{References}

Aberhan, M.N., Nurnberg, S. \& Kiessling, W. 2012. Vision and the diversification of Phanerozoic marine invertebrates. Paleobiology 38, 187-204. DOI 10.1666/10066.1

Agassiz, L. 1847. An introduction to the study of Natural history, in a series of lectures delivered in the hall of the College of Physicians and Surgeons. 58 pp. Greeley \& McElrath, New York.

Arnold, J.M., Landman, N.H. \& Mutvei, H. 2010. Development of the embryonic shell of Nautilus, 373-400. In SAunders, W.B. \& Landman, N.H. (eds) Nautilus The Biology and Paleobiology of a Living Fossil. Plenum Press, New York \& London. DOI 10.1007/978-90-481-3299-7 27

BALASHOV, Z.G. 1964. On the structure and colour patterns of the shell wall in some Ordovician endoceratoids of Baltic. Voprosy paleontologii 4, 106-110. [in Russian]

Barrande, J. 1865-1877. Systême silurien du Centre de la Bo- héme, I. ère partie: Recherches Paléontologiques, vol. II, Classe de Mollusques, Ordre des Céphalopodes, 1865. ser. 6, pl. 1-107; 1866. ser. 7, pl. 108-244; 1867. ser. 1, 712 pp.; 1868. ser. 8, pl. 245-350; 1870. ser. 2, 266 pp., ser. 9, pl. 351-460; 1874. ser. 3, 804 pp.; 1877. ser. 4, 742 pp., ser. 5, 743 pp., supplement 1, 297 pp., supplement 2, pl. 461-544. Privately published, Prague \& Paris.

BERRY, W.E. 1928. Cephalopod adaptations - The record and its interpretation. Quarterly Review of Biology 3, 92-108. DOI $10.1086 / 394295$

BLAKE, J.F. 1882. A monograph of the British fossil Cephalopoda. Part I. Introduction and Silurian species. 248 pp. London. DOI 10.5962/bhl.title.52044

Brazeau, U. \& Friedman, M. 2015. The origin and early phylogenetic history of jawed vertebrates. Nature 520(7548), 490-497. DOI 10.1038/nature14438

Brett, C.E., Boucot, A.J. \& Jones, B. 1993. Absolute depths of Silurian benthic assemblages. Lethaia 26, 25-40. DOI 10.1111/j.1502-3931.1993.tb01507.x

Chapman, E.J. 1857. On the occurrence of the genus Cryptoceras in Silurian rocks. Canadian Journal, New series 2, 264-268.

Chlupáč, I., JAeger, H. \& ZikmundovÁ, J. 1972. The SilurianDevonian boundary in the Barrandian. Bulletin of Canadian Petroleum Geology 20, 104-174.

Collins, D. \& WARD, P.D. 2010. Adolescent Growth and Maturity in Nautilus, 421-432. In Saunders, W.B. \& Landman, N.H. (eds) Nautilus. The Biology and Paleobiology of a Living Fossil. Springer, Dordrecht, Heildeberg, London, New York. DOI 10.1007/978-90-481-3299-7_29

Cотт, H. 1940. Adaptive coloration in animals. 540 pp. Methuen Publishing, London.

Cowen, R., Gertman, R. \& Wiggett, G. 1973. Camouflage patterns in Nautilus, and their implications for cephalopod paleobiology. Lethaea 6, 201-214. DOI 10.1111/j.1502-3931.1973.tb01193.x

DzIK, J. 1984. Phylogeny of the Nautiloidea. Paleontologia Polonica 45, 1-255.

Ferretti, A. \& KŘiž, J. 1995. Cephalopod limestone biofacies in the Silurian of the Prague Basin, Bohemia. Palaios 10, 240-253. DOI 10.2307/3515255

Flower, R.H. 1942. An arctic cephalopod faunule from the Cynthiana of Kentucky. Bulletins of American Paleontology 27, 1-41.

Flower, R.H. \& Kummel, B. 1950. A classification of the Nautiloidea. Journal of Paleontology 24, 604-616.

Foerste, A.F. 1926. Actinosiphonate, Trochoceroid and other cephalopods. Denison University Bulletin, Journal of the Scientific Laboratories 21, 285-383.

Foerste, A.F. 1930a. The colour patterns in fossil cephalopods and brachiopods, with notes on gastropods and pelecypods. Contributions from the Museum of Palaeontology, Michigan 3, 109-150.

Foerste, A.F. 1930b. Port Byron and other Silurian cephalopods. Denison University Bulletin, Journal of the Scientific Laboratories 23, 1-110.

Foerste, A.F. 1933. Black River and other cephalopods from Minnesota, Wisconsin, Michigan, and Ontario (Part 2). 
Bulletin Denison University, Journal of Scientific Laboratories $28,1-136$.

Foerste, A.F. \& Savage, T.E. 1927. Ordovician and Silurian cephalopods of the Hudson Bay Area. Denison University Bulletin, Journal of the Scientific Laboratories 22, 1-107.

FreY, R.C. 1989. Paleoecology of a well-preserved nautiloid assemblage from a Late Ordovician shale unit, southwestern Ohio. Journal of Paleontology 63, 604-620. DOI $10.1017 / \mathrm{S} 0022336000041238$

Gunj, Y-P., Kusunoki, Y. \& Ito, K. 1999. Pigmentation in molluscs: How does global synchronisation arise, 37-63. In SAvazzi, E. (ed.) Functional morphology of the invertebrate skeleton. John Wiley \& Sons, Chichester, New York, Weinheim, Brisbane, Singapore, Toronto.

Hammer, Q. \& Bucher, H. 1999. Reaction-diffusion processes: application to the morphogenesis of ammonoid ornamentation. Geobios 32, 841-852. DOI 10.1016/S0016-6995(99)80866-3

HAVLIČEK, V. \& ŠTORCH, P. 1990. Silurian brachiopods and benthic communities in the Prague Basin (Czechoslovakia). Rozpravy Ústředního ústavu geologického 48, 1-275.

HAVlíčEK, V. \& ŠToRCh, P. 1999. Silurian and Lochkovian Communities of the Prague Basin (Barrandian area, Czechoslovakia), 200-228. In Boucot, A.J. \& Lawson, J.D. (eds) Final report, project Ecostratigraphy. Paleocommunities: A case study from the Silurian and Lower Devonian. Cambridge University Press, Cambridge.

Hedström, H. 1917. Über die Gattung Phragmoceras in der Obersilurformation Gotlands. Sveriges Geologiska Undersokning 15, 1-35.

Hyatt, A. 1883-1884. Genera of fossil cephalopods. Proceedings of the Boston Society of Natural History 22, 273-338.

Hyatt, A. 1894. Phylogeny of an acquired characteristic. American Philosophical Society Proceedings 32, 349-647. DOI 10.5962/bhl.title.59826

Hyatt, A. 1900. Cephalopoda, 502-592. In Zittel, K.A. \& Eastman, C.R. (eds) Textbook of Palaeontology, Vol. 1. MacMillan, Boston.

JoHnSEN, S. 2005. The red and the black: bioluminescence and the colour of animals in the deep-sea. Integrative and Comparative Biology 45, 234-246. DOI 10.1093/icb/45.2.234

KING, A.H. 1999. A review of Volkhovian and Kundan (ArenigLlanvirn) nautiloids from Sweden, 137-159. In OLÓRIOZ, F. \& Rodríguez-Tovar, F.J. (eds) Advancing Research on Living and Fossil Cephalopods. Kluwer Academic, Plenum Publishers, New York. DOI 10.1007/978-1-4615-4837-9_11

Klug, C., Brühwiler, T., Korn, D., Schweigert, G., Brayard, A. \& Tilstey, J. 2007. Ammonoid shell structures of primary organic composition. Palaeontology 50, 1463-1468. DOI 10.1111/j.1475-4983.2007.00722.x

Klug, C., Kröger, B., Kiessling, W., Mullins, G.L., Servais, T., FrÝda, J., Korn, D. \& Turner, S. 2010. The Devonian nekton revolution. Lethaia 43, 465-477. DOI 10.1111/j.1502-3931.2009.00206.x

Kobluk, R.D. \& Hall, R.L. 1976. Preserved colour patterns in Ormoceras westonense from the Middle Ordovician of Quebec. Canadian Journal of Earth Sciences 13, 1479-1481. DOI 10.1139/e76-152
KobluK, D.R. \& MAPES, R.H. 1989. The fossil record, function and possible origins of shell color Patterns in Paleozoic Marine invertebrates. Palaios 4, 63-85. DOI 10.2307/3514734

Koren, T.N., Lenz, A.C., Loydell, D.K., Melchin, M.J., Štorch, P. \&TelLer, L. 1996. Generalized graptolite zonal sequence defining Silurian time intervals for global paleogeographic studies. Lethaia 29, 59-60.

DOI 10.1111/j.1502-3931.1996.tb01837.x

KŘižž, J. 1992. Silurian Field Excursions: Prague Basin (Barrandian), Bohemia. National Museum of Wales, Geological Series 13, 1-110.

KŘíž, J. 1998. Recurrent Silurian-lowest Devonian cephalopod limestones of Gondwanan Europe and Perunica, 183-198. In LANDIng, E. \& Johnson, M.E. (eds) Silurian cycles: Linkages of dynamic stratigraphy with atmospheric, oceanic, and tectonic changes. New York State Museum Bulletin 491.

KŘiž, J., Jaeger, H., PAris, F. \& Schönlaub, H.P. 1986. Př́idolí the fourth subdivision of the Silurian. Jahrbuch der Geologischen Bundesanstalt 129, 291-360.

KRÖGER, B. 2011. Size matters - Analysis of shell repair scars in endocerid cephalopods. Fossil Record 14, 109-118. DOI 10.5194/fr-14-109-2011

Kröger, B \& Aubrechtoví, M. 2019. The cephalopods of the Kullsberg Limestone Formation, Upper Ordovician, central Sweden and the effects of reef diversification on cephalopod diversity. Journal of Systematic Palaeontology 17, 961-995. DOI 10.1080/14772019.2018.1491899

Kröger, B., Servais, T. \& Zhang, Y. 2009. The origin and initial rise of pelagic cephalopods in the Ordovician. PLOS ONE 4(e7262), 1-24. DOI 10.1371/journal.pone.0007262

Manda, Š. \& Turek, V. 2009a. Minute Silurian oncocerids with unusual colour pattern (Nautiloidea). Acta Palaeontologica Polonica 54, 503-512. DOI 10.4202/app.2008.0062

Manda, Š. \& Turek, V. 2009b A Silurian oncocerid with preserved colour pattern and muscle scars (Nautiloida). Bulletin of Geosciences 84, 755-766.

DOI 10.3140/bull.geosci.1168

MANDA, Š. \& TUREK, V. 2015. Colour patterns on Silurian orthocerid and pseudorthocerid conchs from Gotland - palaeoecological implications. Estonian Journal of Earth Sciences 64, 74-79. DOI 10.3176/earth.2015.13

MANDA, Š. \& Turek, V. 2018. Silurian tarphycerid Discoceras (Cephalopoda, Nautiloidea): Systematics, embryonic development and paleoecology. Journal of Paleontology 92, 412-431. DOI 10.1017/jpa.2017.122

MAPES, R.H. \& DAVIS, R.A. 1996. Color patterns in ammonoids, 103-127. In Landman, N. (ed.) Ammonoid Paleobiology. Topic in Geobiology 13. Plenum Press, New York. DOI 10.1007/978-1-4757-9153-2_5

MAPES, R.H. \& Evans, T.S. 1995. The color pattern on a Cretaceous nautiloid from South Dakota. Journal of Paleontology 69, 785-765. DOI 10.1017/S0022336000035290

Mapes, R.H. \& Larson, N.L. 2016. Ammonoid Color Patterns, 25-44. In Klug, C., Korn, D., De Baets, K., Kruta, I. \& Mapes, R.H. (eds) Ammonoid Paleobiology: From Anatomy to Ecology. Springer, Dordrecht.

DOI 10.1007/978-94-017-9630-9_2 
Mapes, R.H., Landman, N.H., Cochran, K., Goiran, C., ForGes, B.R. DE \& Renfro, A. 2010. Early taphonomy and significance of naturally submerged Nautilus shells from the New Caledonia region. Palaios 25, 597-610.

DOI 10.2110/palo.2009.p09-109r

MeInhard, H. 2009. The Algorithmic Beauty of Sea Shells. Fourt edition, with contribution and images by P. Prusinkiewicz and D. R. Fowler. 269 pp. Springer-Verlag, Berlin Heidelberg. DOI 10.1007/978-3-540-92142-4

Miller, S.A. 1877. The American Palaeozoic Fossils: a catalogue of the genera and species with names of authors, dates, places of publication, groups of rocks in which found, and the etymology and signification of the words and an introduction devoted to the stratigraphical geology of the Palaeozoic rocks. 123 pp. Published privately, Cincinnati.

DOI 10.5962/bhl.title.54549

MilLER, A.K. 1947. Tertiary Nautiloids of the Americas. Memoir of the Geological Society of America 23, 1-234. DOI 10.1130/MEM23-p1

MunTZ, W.R.A. 1987. Visual behavior and visual sensitivity of Nautilus pompilius, 231-244. In SAunders, W.B. \& LANDMAN, N.H. (eds) Nautilus: the biology and paleobiology of a living fossil. Plenum, New York. DOI 10.1007/978-1-4899-5040-6 15

Niko, S., Mapes, R. \& Y Acobucci, M. 2009. Arcuatoceras, a New Genus of Nautiloid Cephalopods from the Early Carboniferous in the Midcontinent of North America. Paleontological Research 13, 319-325. DOI 10.2517/1342-8144-13.4.319

PACKARD, A. 1988. Visual tactics and evolutionary strategies, 89-103. In Wiedmann, J. \& Kullmann, J. (eds) Cephalopods: present and past. Schweitzerbart'sche Verlagsbuchhandlung, Stuttgart.

Parsley, R.L., Lawson, M.H. \& †Pojeta, J., JR 2018. A practical and historical perspective on the how and why of whitening fossil specimens and casts as a precursor to their photography. Fossil Imprint 74(3-4), 237-244. DOI 10.2478/if-2018-0016

Peterman, D.J., Barton, C.C. \& Yacobucci, M.M. 2019. The hydrostatics of Paleozoic ectocochleate cephalopods (Nautiloidea and Endoceratoidea) with implications for modes of life and early colonization of the pelgic zone. Palaeontologia Electronica 22.2.24A, 1-29. DOI 10.26879/884

Ruedemann, R. 1921. On color bands in Orthoceras. Bulletin New York State Museum 227, 63-130.

Ruedemann, R. 1925. Some Silurian (Ontarian) faunas of New York. Bulletin of the New York State Museum 265, 5-133.

Saunders, W.B. \& Landman, N.H. (eds) 1987. Nautilus The Biology and Paleobiology of a Living Fossil. 594 pp. Plenum Press, New York \& London. DOI 10.1007/978-1-4899-5040-6

Saunders, W.B. \& Landman, N.H. (eds) 2010. Nautilus The Biology and Paleobiology of a Living Fossil. 594 pp. Plenum Press, New York \& London. DOI 10.1007/978-90-481-3299-7

SAUNDERS, W.B. \& WARD, P.D. 1987. Ecology, distribution, and population characteristics of Nautilus, 137-162. In SAUNDERS, W.B. \& Landman, N.H. (eds) 2010. Nautilus. The Biology and Paleobiology of a Living Fossil. Plenum Press, New York \& London. DOI 10.1007/978-1-4899-5040-6_9
Saunders, W.B., Shimansky, V.N. \& Amitrov, O.V. 1996. Clarification of Nautilus praepomilius Shimansky from the Late Eocene of Kazakhstan. Journal of Paleontology 70, 609-611. DOI 10.1017/S002233600002357X

Schun, F. 1920. Farbreste auf der Schalenoberfläche eines Trocholites. Zeitschrift der Deutschen Geologischen Gesellschaft 72, 181-185.

SeIlacher, A. \& Gishlick, A.D. 2015. Morphodynamics. 531pp. CRC Press, Taylor \& Francis Group. Boca Raton, London, New York. DOI 10.1201/b17557

Slavík, L., ŠTorch, P., MANDA, Š. \& FrÝdA, J. 2014. Integrated stratigraphy of the Ludfordian in the Prague Synform. GFF 136, 238-242. DOI 10.1080/11035897.2013.851733

Stenzel, H.B. 1957. Nautilus, 1135-1142. In HedgPeth, J.W. (ed.) Treatise on Marine Ecology and Paleoecology. Part 1. Memoir of the Geological Society of America 67. DOI 10.1130/MEM67V1-p1135

Stenzel, H.B. 1964. Living Nautilus, 59-93. In Moore, R.C. (ed.) Treatise on Invertebrate Paleontology, Mollusca 3. The University of Kansas Press, Lawrence.

Štorch, P., Manda, Š. \& Loydell, D.K. 2014. The Early Ludfordian leintwardinensis graptolite Event and the GorstianLudfordian boundary in Bohemia (Silurian, Czech Republic). Palaeontology 57, 1003-1043. DOI 10.1111/pala.12099

Stridsberg, S. 1985. Silurian oncocerid cephalopods from Gotland. Fossils and Strata 18, 1-65.

Swan, A.R.H. \& Saunders, W.B. 2010. Morphological Variation in Nautilus from Papua New Guinea, 85-103. In SAUnders, W.B. \& Landman, N.H. (eds) Nautilus. The Biology and Paleobiology of a Living Fossil. Plenum Press, New York \& London. DOI 10.1007/978-90-481-3299-7_6

Sweet, W.C. 1964. Nautiloidea-Oncocerida, 277-319. In Moore, R.C. (ed.) Treatise on Invertebrate Paleontology, Part K, Mollusca 3, Cephalopoda. Geological Society of America and The University of Kansas Press, Boulder and Lawrence.

Sweet, W.C. \& Leutze, W.P. 1956. A restudy of the Silurian nautiloid genus Priesteroceras Ruedemann. Journal of Paleontology 30, 1159-1165.

Teichert, C. 1939. Nautiloid Cephalopods from the Devonian of Western Australia. Journal of the Royal Society of West Australia 25, 103-121.

Teichert, C. 1964. Morphology of hard parts, 13-53. In Moore, R.C. (ed.) Treatise on Invertebrate Paleontology, Part K, Mollusca 3, Cephalopoda. The Geological Society of America, Lawrence.

Teichert, C. \& Glenister, B.F. 1954. Early Ordovician cephalopod fauna from northwestern Australia. Bulletins of American Paleontology 35, 7-112.

Teichert, C. \& Matsumoto, T. 1987. The Ancestry of the Genus Nautilus, 25-32. In SAunders, W.B. \& Landman, N.H. (eds) Nautilus: Biology and Paleobiology of a Living Fossil. Plenum Press, New York \& London. DOI 10.1007/978-1-4899-5040-6_2

Turek, V. 1990. Color patterns on Silurian and Devonian cephalopods of Central Bohemia, 81. In Abstracts $3^{\text {rd }}$ Symposium of cephalopods: Present and past. Lyon. 
TUREK, V. 1992. Orthoceras Limestones and cephalopods of the Kopanina/Přídolí boundary beds (Silurian) in active part of the Kosov quarry near Beroun. Časopis Národního muzea, $\check{R} a d a$ prírodovědná $158,108$.

TuREK, V. 2009. Colour patterns in Early Devonian cephalopods from the Barrandian Area: Taphonomy and taxonomy. Acta Palaeontologica Polonica 54, 491-502.

DOI 10.4202/app.2007.0064

Turek, V. \& MANDA, Š. 2010. Variability of colour pattern and shell malformations in Silurian nautiloid Peismoceras Hyatt, 1884. Journal of the National Museum, Natural History 179, 171-178

TureK, V. \& MANDA, Š. 2011. Colour pattern polymorphism in Silurian nautiloid Phragmoceras Broderip, 1839. Bulletin of Geosciences 86, 91-105. DOI 10.3140/bull.geosci.1240
VOKÁČ, V. 1999. Trilobitová společenstva hraničního intervalu ludlow-prrídolí (silur) v novém profilu v lomu Kosov u Berouna (pražská pánev, Čechy). Palaeontologia Bohemiae 5(9), 70-74.

WARD, P.D. 1987. The natural history of Nautilus. 267 pp. Allen \& Unwin, Boston, London, Sydney, Wellington.

Ward, P.D., Dooley, F. \& Barord, J.G. 2016. Nautilus: biology, systematics, and paleobiology as viewed from 2015. Swiss Journal of Palaeontology 135, 169-185.

DOI 10.1007/s13358-016-0112-7

Westermann, G.E.G. 1998. Life Habits of Nautiloids, 263-298. In SAVAzzI, E. (ed.) Functional Morphology of the Invertebrate Skeleton. John Wiley, London.

Williams, T.S. 2017. Molluscan shell colour. Biological reviews 92, 1039-1058. DOI 10.1111/brv.12268 